\title{
Evaluating the impacts of volcanic eruptions using RiskScape
}

\author{
Natalia I. Deligne ${ }^{1 *}$, Nick Horspool', Silvia Canessa', lain Matcham¹, George T. Williams ${ }^{2,3}$, Grant Wilson ${ }^{2,4}$ \\ and Thomas M. Wilson ${ }^{2}$
}

\begin{abstract}
RiskScape is a free multi-hazard risk assessment software programme jointly developed by GNS Science and the National Institute of Water and Atmospheric Research (NIWA) in New Zealand. RiskScape has a modular structure, with hazard layers, assets, and loss functions prepared separately. While RiskScape was originally developed for New Zealand, given suitable hazard and exposed asset information, RiskScape can be run anywhere in the world. Volcanic hazards are among the many hazards considered by RiskScape. We first present RiskScape's framework for all hazards, and then describe in more detail the five volcanic hazards - tephra deposition, pyroclastic density currents, lava flows, lahars, and edifice construction/excavation. We describe how loss functions were selected and developed. We use a scenario example to illustrate not only how RiskScape's volcanic module works but also how RiskScape can be used to compare across natural hazards.
\end{abstract}

Keywords: Fragility functions, Risk assessment, RiskScape, Volcanic hazard, Vulnerability functions

\section{Introduction}

Volcanic eruptions are multi-hazard events that have a range of impacts ranging from total devastation and mass fatalities to minor societal nuisance (e.g., Auker et al., 2013; Wilson et al., 2014; Loughlin et al., 2015; Sigurdsson, 2015). Eruptions can last minutes to decades, and can produce concurrent, sequential, and/or recurrent hazards. In general, more severe impacts are close to the vent, although in some cases destructive hazards can travel 10s of $\mathrm{km}$ from the vent (e.g., Dufek et al., 2015; Vallance and Iverson, 2015).

Through the millennia, cultures have engaged in a variety of loss mitigation strategies, such as declaring areas near volcanoes taboo or passing down stories through the generations permitting identification of the warning signs and hazards of a volcanic eruption (e.g., Cashman and Cronin, 2008). In historic time, events and observations have been written down for posterity, and in the last few decades mathematical models have been created to understand and forecast volcanic hazards.

Across all natural hazards, modern loss mitigation strategy is founded on understanding hazards and

\footnotetext{
* Correspondence: N.Deligne@gns.cri.nz

'GNS Science, 1 Fairway Drive, Avalon, Lower Hutt 5010, New Zealand Full list of author information is available at the end of the article
}

impacts, often mathematically, and making decisions on land use planning, insurance policy terms, and governmental policies based on the results of these models. It is increasingly important on a local, regional, national and international level to have robust, science-based, reproducible hazard, impact, and probabilistic risk assessments to inform decisions concerning living with and being exposed to natural hazards - i.e., disaster risk reduction.

Risk is generally defined as a function of hazard, asset exposure, and consequence (Eq. 1; Fournier d'Albe, 1979).

$$
\text { Risk }=f(\text { hazard }, \text { asset }, \text { consequence })
$$

In general, risk has a probabilistic component: the hazard variable can be the probability of a hazard or a hazard of a certain intensity occurring, and the consequence can be the probability of a certain outcome (e.g., devastation) occurring given the combination of the hazard and the exposed asset (Douglas, 2007). Impact assessment is more deterministic, and examines the outcome of the interaction between a hazard of a given intensity and an asset with particular qualities or attributes (Panza et al., 2011).

Risk assessment is an important tool in any disaster risk reduction activity. The 2015-2030 Sendai Framework for Disaster Risk Reduction (United Nations, 
2015), which builds on the previous Hyogo Framework for Action (HFA), outlines a framework for disaster risk reduction. The SFDRR has four 'Priorities for Action' that are required to be undertaken across all sectors and at different levels of administration (local to global) to underpin disaster risk reduction activities. The first priority of action is Understanding Risk. Central to the first priority is the undertaking of risk assessment to provide baseline risk information for all stages of a disaster risk reduction activity, as well as providing a means of assessing the benefit of certain mitigation activities.

Over the past decade a number of regional and national level risk assessments have been undertaken in New Zealand to identify the baseline level of risk for a range of natural hazards. The understanding of earthquake risk in New Zealand is well advanced through national level studies by Cousins (2004) and Dowrick et al. (2004), and more recently at a regional level including many secondary earthquake hazards, such as tsunami (Cousins et al., 2009) and fire following (Cousins et al., 2012, Thomas et al., 2012). Following the 2004 Indian Ocean Tsunami, a national level tsunami risk assessment for New Zealand was conducted by Berryman et al. (2005) and later updated by Horspool et al. (2015). The results highlighted that tsunami have the potential to cause greater casualties than earthquakes in New Zealand, while earthquakes are likely to cause greater economic loss.

Previous work on New Zealand volcanic risk includes estimation of the risk to human life and building damage for Auckland, New Zealand, from all New Zealand eruption sources (Magill and Blong, 2005a, b), and evaluation of risk from tephra deposition (e.g. Johnston et al., 2011) based on the probabilistic ash fall model of Hurst and Smith (2010). The Magill and Blong (2005a, b) papers compared risk from several hazards in addition to volcanic eruptions, including flooding and climate change. Internationally, workers have evaluated impact and/or risk to communities from one (e.g., Trusdell, 1995; Lirer and Vitelli, 1998; Lavigne, 1999; Spence et al., 2005a; Favalli et al., 2009; Biass et al., 2012; Gehl et al., 2013) to several volcanic hazards (e.g., Pomonis et al., 1999; Spence et al., 2005b; Lirer et al., 2010). There have been efforts to characterise the effects of compounding volcanic hazards (e.g., Zuccaro et al., 2008), and work towards multi-hazard risk assessment for several hazards including volcanic hazards (e.g., Thierry et al., 2008; Marzocchi et al., 2012).

There is an increasing need from regional and central government organisations for updated and dynamic quantitative natural hazard risk assessment, including volcanic hazards, to better identify, assess and compare risks, and evaluate potential mitigation strategies (LGNZ, 2014; NIU, 2015). The Riskscape programme has been funded to undertake quantitative natural hazard risk assessment, including building a software platform designed to evaluate impact and risk from natural hazards.

In this paper we provide an overview of RiskScape, a free risk assessment software programme, with a focus on describing how volcanic hazards and their impacts are evaluated. We finish with an example of how RiskScape can be applied to evaluate the impact of a volcanic eruption in Auckland, New Zealand's largest city.

\section{RiskScape overview}

RiskScape is a free multi-hazard risk assessment software programme, jointly developed by GNS Science (New Zealand's geological agency) and the New Zealand National Institute of Water and Atmospheric Research (NIWA). The aim of RiskScape is to provide a tool to organisations and researchers to estimate the impacts and losses for assets resulting from natural hazards. It is available at https://www.riskscape.org.nz/ and is free following user registration. There are other risk assessment tools available (e.g., CAPRA, HAZUS, InaSAFE, OpenQuake); the aim of RiskScape is to provide a tool to compare the consequences of a wide suite of hazards, full transparency on how the evaluation is done, and for the tool to be free to use without the need for any propriety software. RiskScape provides assessment of numerous natural hazards, including earthquakes, flooding, tsunami, storms, wildfires, drought, and volcanic hazards. As such, the consequences of a variety of hazards can be compared in a single platform. RiskScape is presently scenario-driven, although in the future it is planned to have a probabilistic component for probabilistic risk evaluation. To date, it has been used in New Zealand and in the wider Asia-Pacific region.

A key feature of RiskScape is its modular structure (Fig. 1): the hazard (e.g., volcanic tephra deposition) is characterised in the hazard module, assets (e.g., the built environment, people) are stored in the asset module, and the consequences (e.g., vulnerability and fragility functions) are captured in the vulnerability module. The final RiskScape programme outputs are maps and/or tables characterising impact and loss.

RiskScape can allow the evaluation of a single hazard, or cascading hazards such as earthquake ground shaking followed by liquefaction, or multiple volcanic hazards during a single eruption. At present the multiple volcanic hazards are treated independently, but the intent is to modify this in the future. Thus, there is no current mechanism for evaluating compound volcanic impacts - e.g., the impact of a building first exposed to tephra fall and then several weeks later, exposed to lahar. As such, in the instance of modelling the effects of multiple volcanic hazards, at this stage care needs to be 


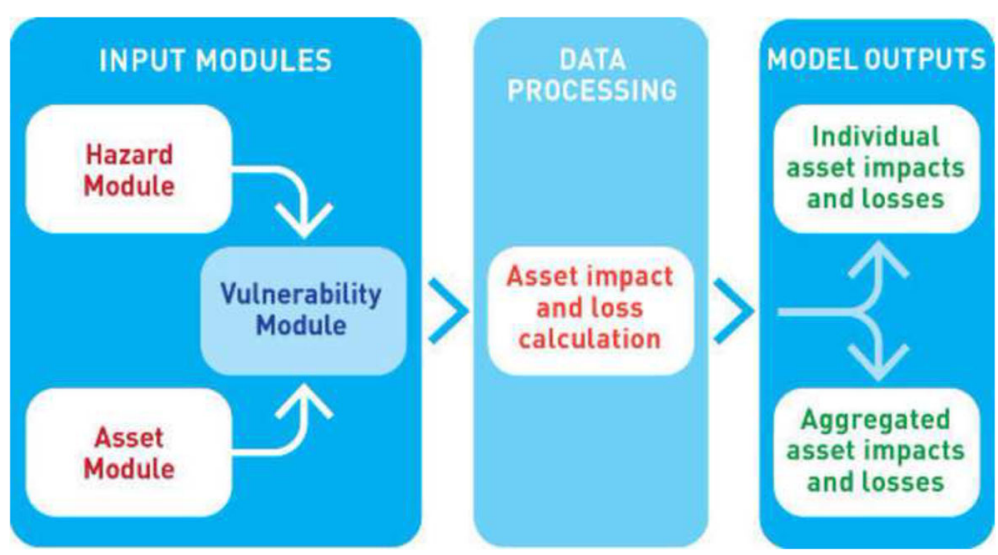

Fig. 1 RiskScape's modular structure

taken to avoid double-counting losses. Additionally, RiskScape currently assumes all impact happens during initial exposure - there is no consideration of potential impacts caused by delayed clean-up or long-term effects.

RiskScape calculates impacts to assets on an individual asset-by-asset basis. For each asset the hazard intensity at the site is evaluated against the vulnerability or fragility function to estimate the impact. If the vulnerability model is deterministic (no uncertainty) then the results are reproducible as the mean damage ratio is always evaluated. If the model incorporates uncertainty in the damage ratio then the user can evaluate the mean damage ratio, or sample from the uncertainty distribution (damage ratio as a function of intensity) using a Monte Carlo simulation method. Fragility functions are inherently probabilistic and the user can calculate the most likely damage state or sample from the distribution of damage states using Monte Carlo simulation methods to generate a distribution of damage states. For both approaches the individual asset results can be assessed or aggregated to a user-defined aggregation unit such as suburb, or census administration units.

For further details of the RiskScape model, the reader is referred to Schmidt et al. (2011).

\section{Hazard module}

Within the RiskScape framework, the hazard module sets the extent and intensity of the hazard of interest. Here, hazard intensity refers to the severity of the hazard, measured with a Hazard Exposure Measurement Unit (HEMU; see next paragraph). For some hazards, such as earthquake shaking intensity or volcanic tephra deposition, the user can select the source and input parameters - for earthquakes this is the epicentre and magnitude, whereas for volcanic tephra deposition this is the volcano, eruption size, and wind model. RiskScape then provides on-the-fly modelling of the extent and intensity of the hazard - shaking for earthquakes or deposit thickness for volcanic ash. For other hazards which have greater computation requirement for their associated hazard models, such as flooding or lava flows, RiskScape does not provide on-the-fly modelling - rather, the user must upload or select a pre-uploaded file of the extent and severity of the hazard. Due to computational demands, it is unlikely on-the-fly modelling for these hazards will be provided in the short term. Hazard layers may be input in any coordinate system (the user must specify which one) and for anywhere in the world. As RiskScape is a scenario based tool, the magnitudefrequency distribution of a given hazard is not required. However, the probability of occurrence of a particular scenario is useful to know, especially when impacts between hazards are compared in a multi-hazard risk assessment using RiskScape.

Hazard intensity is a key parameter input to vulnerability models. The unit with which intensity is described is the Hazard Exposure Measurement Unit (HEMU). For RiskScape and other risk assessment purposes, the most useful HEMU measures a hazard characteristic that is most strongly correlated to (or causes) damage and preferably is measureable after the event and/or a forward physical model output (e.g., Wilson et al., 2014). Examples of HEMUs used in RiskScape for other hazards include Modified Mercalli Intensity (MMI) or peak ground acceleration for earthquakes, flood water depth and velocity, and tsunami flow depth. In the example of floods and tsunami, velocity (which may at times act as a proxy for discharge) may be most strongly correlated to damage, yet often only high water levels are available post-event; in such cases while the ideal HEMU would be velocity, high water levels are the HEMU used in the majority of fragility and vulnerability functions.

As RiskScape was selected as the primary way to evaluate volcanic risk for Auckland, New Zealand by the Determining Volcanic Risk for Auckland (DEVORA) research programme, certain decisions regarding hazards 
and default parameters have been made considering the Auckland context, explained further when appropriate in this paper. Auckland is home to one third of New Zealanders and overlies the mostly monogenetic Auckland Volcanic Field (AVF; Fig. 2): it is thus potentially vulnerable to a local volcanic eruption and associated proximal hazards and volcanic ash from other New Zealand volcanoes.

We selected at least one HEMU for each volcanic hazard currently available in RiskScape (volcanic tephra deposition, pyroclastic density currents (PDCs), lava flows, lahar, and edifice formation (development of a new cone or maar); Table 1). We did this by reviewing available literature for which HEMUs cause damage or reduced functionality for a wide range of assets types, including buildings, people, and critical infrastructure. The HEMUs which were relevant for impact to the greatest number of asset types were then shortlisted. We then considered the ease of realistically modelling or determining each HEMU. We then selected the HEMU on the balance of relevance and determinability. For hazards that can have relatively binary impacts (Wilson et al., 2014), we allowed the option of providing hazard extent and picked a default HEMU in the case of no other available information. This default value is based on either represented values measured or inferred for the AVF, or values observed or modelled at representative volcanoes outside of New Zealand. The default value is set independent of the consequences of the selected default HEMU. Below, we discuss our HEMU selection process for each hazard.

Currently, on-the-fly ash dispersal modelling is only available for New Zealand volcanoes. However, if a user has a raster of a hazard layer anywhere in the world for

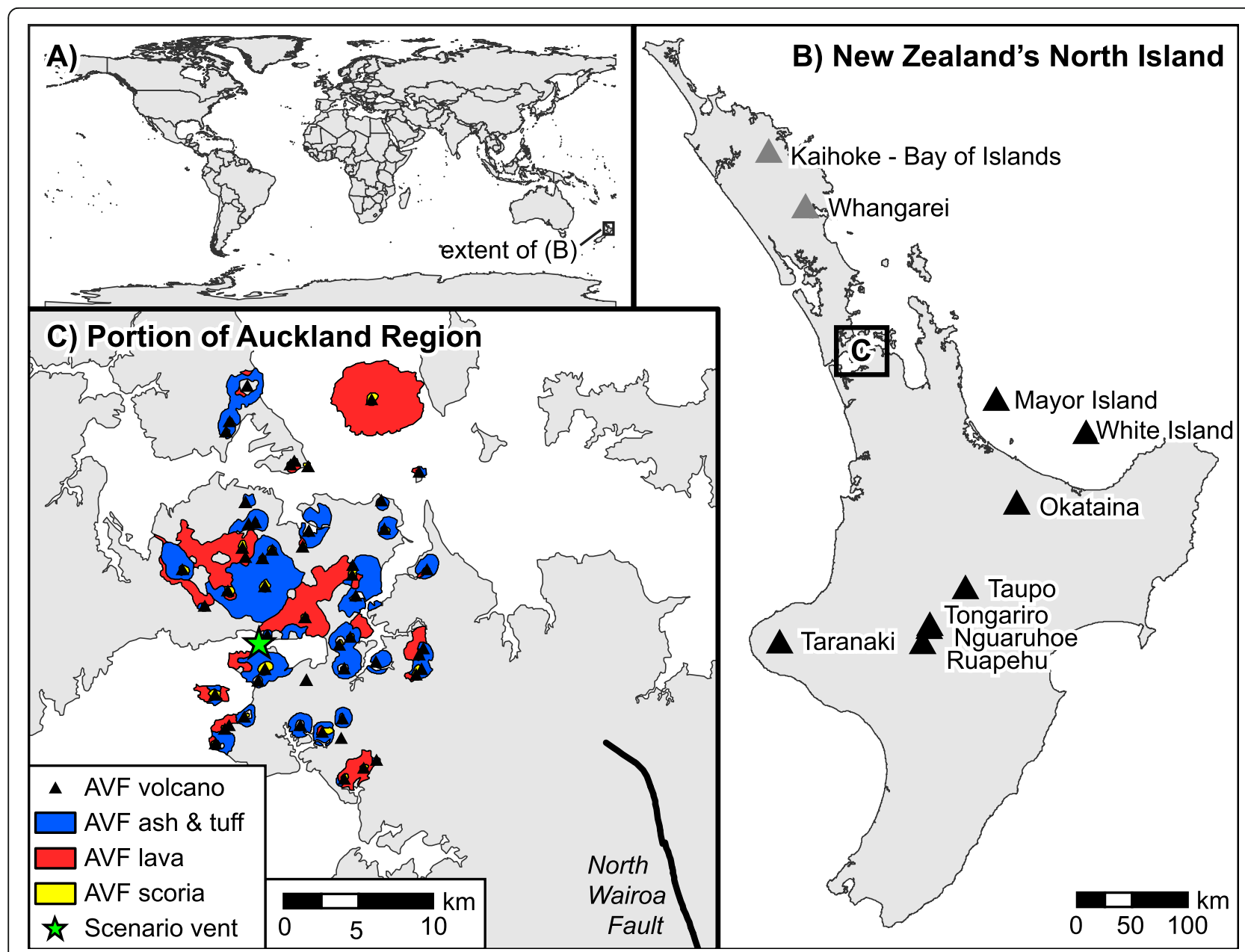

Fig. 2 Location map for New Zealand's North Island, its volcanoes, and the Auckland Volcanic Field. a Map of the world, with the extent of (b) indicated with a box. b New Zealand's North Island; in black are volcanoes with on-the-fly ash modelling capabilities in RiskScape, and in grey are other volcanoes. The extent of (c) is indicated with a black box. c Large portion of the Auckland region and the Auckland Volcanic Field. The site of the Māngere Bridge scenario is indicated with a green star, and the North Wairoa Fault is shown with a thick black line 
Table 1 RiskScape's volcanic hazards, associated hazard exposure measurement unit (HEMU), and input formats for hazard module

\begin{tabular}{|c|c|c|}
\hline Volcanic hazard & HEMU & Input format \\
\hline Volcanic ashfall & Thickness (mm) & Raster \\
\hline Pyroclastic density current (PDC) & $\begin{array}{l}\text { Damage } \\
\text { - Dynamic pressure (kPa) } \\
\text { - Presence/absence (default } 50 \mathrm{kPa}) \\
\text { Clean-up } \\
\text { - Deposit thickness (mm) }\end{array}$ & $\begin{array}{l}\text { Raster (recommended) } \\
\text { Presence/absence polygon }\end{array}$ \\
\hline Lava flow & $\begin{array}{l}\text { - Height }(\mathrm{m}) \\
\text { - Presence/absence (default } 5 \mathrm{~m} \text { ) }\end{array}$ & $\begin{array}{l}\text { Raster (recommended) } \\
\text { Presence/absence polygon }\end{array}$ \\
\hline Lahar & $\begin{array}{l}\text { Damage } \\
\text { - Dynamic pressure }(\mathrm{kPa}) \\
\text { - Inundation depth }(\mathrm{m}) \\
\text { - Presence/absence (default } 5 \mathrm{kPa} \text { and } 2 \mathrm{~m}) \\
\text { Clean-up } \\
\text { - Deposit thickness }(\mathrm{m}) \\
\text { - Presence/absence (default } 2 \mathrm{~m})\end{array}$ & $\begin{array}{l}\text { Raster (recommended) } \\
\text { Presence/absence polygon }\end{array}$ \\
\hline Edifice & $\begin{array}{l}\text { - Height }(\mathrm{m}) \text {, positive for built edifice, negative for depression } \\
\text { - Presence/absence - cone (default }+10 \mathrm{~m} \text { ) } \\
\text { - Presence/absence - caldera or maar (default }-10 \mathrm{~m} \text { ) }\end{array}$ & $\begin{array}{l}\text { Raster (recommended) } \\
\text { Presence/absence polygon }\end{array}$ \\
\hline
\end{tabular}

In the future, ballistics will be an additional hazard considered by RiskScape

one of the five hazards (see Table 1) the user can upload it into RiskScape.

\section{Hazard exposure measurement units \\ Volcanic tephra deposition}

The fallout of tephra and in particular ash (tephra that is $<2 \mathrm{~mm}$ in diameter) from a volcanic plume and cloud can cover thousands of $\mathrm{km}^{2}$ and has the greatest footprint of any volcanic hazard (Blong, 1984). As ash generally accounts for the majority of spatial exposure from tephra fall, this hazard is referred to in RiskScape as "Volcanic ashfall". With the exception of possible health impacts, from a vulnerability and fragility function point of view there is little difference between ash and coarser particles apart from size (Horwell and Baxter, 2006; Wilson et al., 2015; Cashman and Rust, 2016), so the same functions can be applied to ash and coarser tephra. Ballistics (volcanic projectiles; Bower and Woods, 1996) are considered a separate hazard.

Ash tends to be disruptive rather than destructive (Wilson et al., 2012; Wilson et al., 2015), with even small amounts causing reduced functionality of key services such as the electrical transmission network or road usability. Most volcanic ash impacts are due to physical properties (e.g., deposit thickness, density, abrasiveness; Wilson et al., 2014; Wilson et al., 2015). Ash particle grain-size distribution and crystallinity content are also a key factor in health impacts to humans (Horwell and Baxter, 2006). However, surface chemistry also matters - ash particles acquire a soluble salt coating following interaction with volcanic gases in the volcanic plume (Stewart et al., 2009). This property is important for impacts to electrical transmission lines - the reactive surface is conductive when moist, causing flashovers (short-circuits; Wardman et al., 2012). Water supplies are also vulnerable as the salt coating is soluble and so can contaminate water (Stewart et al., 2009).

We thus identified three candidate HEMUs for tephra: static load, thickness, and a measurement unit related to surface chemistry. Static load is the most appropriate measurement unit for building damage (Spence et al., 2005a, b; Jenkins et al., 2014a) and also contributes to damage to agricultural sectors and some infrastructure (Wilson et al., 2015), yet is generally well-correlated with thickness. It is an output of some tephra dispersion models (e.g., Tephra2; Bonadonna et al., 2005). Thickness contributes to damage and functionality disruption for most infrastructure (Wilson et al., 2014), is easily measured in the field, and is also an output of some tephra dispersion models (e.g., ASHFALL; Hurst, 1994). Surface chemistry contributes to electrical network disruptions, and can affect water quality and have agricultural consequences (Wilson et al., 2015), but is difficult to model with no easily determinable measure.

Given the general correlation between static load and tephra thickness, and the greater ease of measuring thickness, we adopt a HEMU of tephra deposit thickness for RiskScape, measured in $\mathrm{mm}$.. The hazard layer is input in raster format, either from a user-provided raster or one generated through on-the-fly modelling within the RiskScape programme. Isopach polygons are not accepted - these must be first converted to raster format. The user may specify whether ash is dry or wet. To convert from thickness to static load, dry tephra density is assumed to be $1000 \mathrm{~kg} / \mathrm{m}^{3}$ (Crosweller et al., 2012) and wet tephra density is assumed to be $1500 \mathrm{~kg} / \mathrm{m}^{3}$ (Spence et al., 2005a, b). 


\section{On-the-fly volcanic ash dispersion modelling}

RiskScape allows users to undertake on-the-fly volcanic ash dispersion modelling for New Zealand volcanoes using the ASHFALL model (Hurst, 1994). All NZ volcanoes listed in the Global Volcanism Program are included for on-the-fly modelling; Ngauruhoe, a prominent sub-feature of Tongariro volcano, is listed as a separate volcano from Tongariro in RiskScape. The exception is the volcanic fields (the Auckland, Kaihohe - Bay of Islands, and Whangarei volcanic fields; Fig. 2): these are currently omitted because we haven't yet resolved how to best represent these given that the next vent will likely be new and definitely will be in an unknown location. Furthermore, for Kaihohe - Bay of Island and Whangarei, very little is known about the future potential of eruptive activity. However, for any of the volcanic fields, or volcanoes outside of New Zealand, a user may upload their own raster ash deposition file.

ASHFALL requires eruption volume, column height, grain settling velocity distribution, and a 2-D wind field above the vent. The 2-D wind field above the vent can vary over the course of the dispersion modelling (i.e., a single eruption).

The user may select a small, moderate, or large eruption, which calls on volume and column height parameters in Mastin et al. (2009a, b). The grain settling velocity distribution is based on the Vesuvius $79 \mathrm{AD}$ eruption (Mayor Island, Nguaruhoe, Ruapehu, Tongariro, Taranaki, and White Island; Macedonio et al., 1990; Hurst and Smith, 2004; Hurst and Smith, 2010), and the Hatape eruption from Taupo (Okataina and Taupo; Walker, 1981; Hurst and Smith, 2004; Hurst and Smith, 2010). In the future, when we include various vent options for the Auckland Volcanic Field, we will use the 1973 Heimaey eruption (Self et al., 1974; Hurst and Smith, 2010) distribution. Finally, for all volcanoes, a horizontal diffusion coefficient of $12,000 \mathrm{~m}^{2} / \mathrm{s}$ and a Suzuki constant of 5 is applied (Hurst, 1994).

Default wind files are provided for the months of May to October only, along with a "typical" southerly wind pattern. These are based New Zealand Limited Area Model weather model outputs near Ruapehu for specific dates in 2008. The vertical profile for each wind files changes every $2 \mathrm{~h}$ over a period of $96 \mathrm{~h}$.

It is planned that Tephra2 will be included as a second on-the-fly model (Bonadonna et al., 2005; Bonadonna et al., 2010). While the eruption volume (mass) and column height will be obtained following Mastin et al. (2009a, b), we will use the default parameters provided by the Tephra2 team on vhub (Bonadonna et al., 2010). The configuration files for Mayor Island, Nguaruhoe, Ruapehu, Tongariro, Taranaki, and White Island will be based on Irazu 1963 (Bonadonna et al., 2010), Okataina and Taupo will be based on Pululagua 2450 BP (Volentik et al., 2010), and the AVF will be based on Cerro Negro (Bonadonna et al., 2010).

\section{Pyroclastic density currents (PDCs)}

PDCs are gravity-driven flows of volcanic gases and particles. These are extremely damaging fast-moving (10s to $100 \mathrm{~s}$ of $\mathrm{km} / \mathrm{h}$; Lube et al., 2007; Cas et al., 2011; Komorowski et al., 2013; Roche, 2015), often quite hot flows $\left(>100{ }^{\circ} \mathrm{C}\right.$, generally $\left.300-700{ }^{\circ} \mathrm{C}\right)$ typically formed from volcanic column collapse or lava dome collapse (Dufek et al., 2015). Damage to the built environment is driven by dynamic pressure, $P_{d y n}$ (Spence et al., 2004; Jenkins et al., 2014a), which is a function of flow density, $\rho$, and velocity, $v$ (Valentine, 1998):

$$
P_{d y n}=\frac{1}{2} p v^{2}
$$

The entrainment of debris such as parts of buildings, rocks and trees into PDCs can increase the severity of damage as these will act as missiles within the flow (Spence et al., 2004. High temperatures are also damaging, although thermal damage can be indirectly caused by PDCs entering a building and then igniting flammable furnishings as well as from direct thermal damage to a building (e.g., Baxter et al., 2005). PDCs also leave a deposit, which may require clean-up if site rehabilitation is undertaken.

We thus identified four candidate HEMUs for PDCs: presence/absence (inundation extent), dynamic pressure, temperature, and deposit thickness. Complementary HEMUs are exposure duration, which has been shown to affect building occupant survivability (Baxter et al., 1998) and potentially thermal affects (Spence et al., 2007), and missile entrainment. Presence/absence is very crude, but is an output of several PDC models (e.g., PFz; Widiwijayanti et al., 2009), and is appropriate for hazards with binary impacts (total damage given exposure). Dynamic pressure is the most appropriate for buildings and the built environment (Spence et al., 2004; Jenkins et al., 2014a; Neri et al., 2015), and is an output of some models (e.g., PYFLOW; Dioguardi and Dellino, 2014). Temperature is more challenging: there is a large range in PDC temperatures, and these temperatures can vary greatly even within a single PDC (Cole et al., 2015), which makes it difficult to model. Deposit thickness is not well correlated with damage (e.g., Neri et al, 2015), but is a key parameter for clean-up (Hayes et al., 2015). Both exposure duration and missile entrainment are difficult to model; while they are mentioned in the literature (e.g., Baxter et al., 1998; Esposti Ongaro et al., 2002), they are not incorporated into models at present. Thus, the first three HEMUs along with exposure duration relate to damage, and relate to dynamic 
aspects of PDCs, while deposit thickness is more strongly related to clean-up and related to static aspects of PDCs. We will now discuss these two different aspects in more detail.

\section{PDC dynamic HEMUs}

Given the difficulty in modelling PDC temperature, and the importance of dynamic pressure in causing damage to the built environment, we adopt a HEMU of dynamic pressure in kilopascals $(\mathrm{kPa})$ in RiskScape. The hazard layer is input in raster format, with the raster provided by the user. However, given that model outputs of dynamic pressure aren't always readily available, and PDCs can in the first order be considered a binary hazard (Wilson et al., 2014), we also provide an option of having a polygon (shapefile) denoting presence/absence. For polygons, we have selected a default value of $50 \mathrm{kPa}-$ this is lower than the highest modelled $P_{d y n}$ for the Auckland Volcanic Field (over $100 \mathrm{kPa}$; Brand et al., 2014), but large enough to cause near-binary impacts (Valentine, 1998). This will likely overestimate the hazard; documentation warns users uploading a presence/absence file that RiskScape will most likely overestimate the total impact and loss. Refining this approach for PDC from AVF eruptions, and for PDC from other volcano types is a future priority.

\section{PDC static HEMUs}

As previously stated, PDCs cause damage during emplacement, and leave a deposit that may need to be cleaned up for area rehabilitation. At present the best estimates for clean-up of volcanic debris are for volcanic tephra deposition (Hayes et al., 2015). Consequently, for clean-up considerations, we adopt the same HEMU for the PDC deposit as volcanic ashfall (thickness); we do not consider possible building or other debris resulting from the deposit at this stage.

\section{Lava flow}

Lava flows are flows of molten rock that solidify as the flow cools and crystallises; the resulting "deposit" is a solid rock that extends over the entire flow path. Lava flows can be centimetres to tens of metres thick (MacDonald, 1953), have emplacement temperatures of 800-1200 ${ }^{\circ} \mathrm{C}$ (Kilburn, 2015) and can take weeks to months to cool to ambient temperatures (e.g., Patrick et al., 2004; Patrick et al., 2005). However, it is possible to get very close to active lava flows unharmed and unburnt, and in all but rare cases lava flows are slow enough to be outwalked (Blong, 1984).

Lava flows can cause damage in several ways. The mere presence of lava can cause damage by inundation or burial (Harris, 2015). Additionally, lava can cause damage due to its dynamic pressure, which can lead to wall collapse and foundation failure, and building displacement (Blong, 1984, Harris, 2015, Jenkins et al., 2017). Lava flows can also cause damage through ignition or explosions (e.g., Jenkins et al., 2017). Lava flow modelling outputs are usually extent, thickness, or probability of a cell being covered, and models regarding physical properties tend to focus on rheology (e.g., Felpeto et al., 2001; Vicari et al., 2007; Castruccio et al., 2014).

We thus identified three candidate HEMUs: presence/ absence (inundation extent), thickness, dynamic pressure, and temperature. Inundation extent is crude, but is an output of the majority of lava flow models (Cordonnier et al., 2015). It is also the diagnostic HEMU in the vast majority of cases - was the area impacted by any amount of lava. Thickness is a closely related HEMU which provides slightly more information, and is an output of a number of lava flow models (Cordonnier et al., 2015). Lava flow thickness may become important during recovery, particularly for buried infrastructure - e.g., there may be a difference when determining whether a network is abandoned or maintained if it is covered in 1 or $10 \mathrm{~m}$ of lava. Dynamic pressure is clearly important (e.g., Jenkins et al., 2017), but isn't a standard model output and is also difficult to estimate in the field. Finally, temperature varies quite a bit over the course of lava flow emplacement, and is not a standard model output.

We thus adopted a HEMU of thickness in $\mathrm{m}$, input as a raster or a single polygon denoting lava flow extent. In the case of the latter, a default thickness of $5 \mathrm{~m}$ is applied within the lava flow polygon - within but on the low end of the range of mean thicknesses worldwide for mafic flows (3-20 m; Kilburn, 2015). For AVF lavas, this is also on the low end of the range of observed thicknesses (3 - > 40 m; Kereszturi et al., 2012).

\section{Lahar}

Lahars are debris flows comprised of volcaniclastic material (Iverson, 1997). Lahars follow topographic lows (i.e., river channels) and can travel $10 \mathrm{~s}$ of $\mathrm{km}$ from the vent (Pierson et al., 1990). Lahars may occur during an eruption or years after an eruption as rain remobilises loose volcaniclastic material (e.g., Gran et al., 2011). As such, lahars can be a recurrent hazard for many years following a large explosive eruption, particularly in areas with considerable rainfall. Lahars are extremely damaging due to their transportation of large boulders and debris, ability to inundate large areas with mud, and their high dynamic pressure, and leave deposits which may require removal to restore or rehabilitate an area for anthropogenic uses. Damage to the built environment is primarily driven by lahar inundation and dynamic pressure (Jenkins et al., 2015). Whereas PDCs owe their high dynamic pressure to velocity, lahars have a high dynamic pressure due to their density (Eq. 1; 
Gudmundsson, 2015). However, lahar modelling and hazard evaluation (e.g., Schilling, 1998) is often most concerned with hazard extent.

We identified several candidate HEMUs: presence/absence (inundation extent), inundation depth (thickness), velocity, discharge, and impact (dynamic) pressure. Similar to PDC, a complementary HEMU is entrainment of large boulders and other debris, which can include trees and buildings. Presence/absence is crude, but is appropriate for binary impacts, and is the output of the most commonly used lahar model, LAHARZ (Schilling, 1998). Inundation depth is relatively easy to measure in the field, and can thus be empirically tied to observed damage. Velocity and discharge are difficult to measure instrumentally, as gauges used in rivers are generally destroyed by lahars. Entrainment of ambient material (e.g., trees, buildings) is challenging and requires a detailed inventory landscape, which is beyond RiskScape's current capabilities. For the built environment, dynamic pressure is likely the key damaging parameter, although for fatalities it is likely to be inundation depth; deposit thickness most strongly relates to clean-up. We will now discuss these two different aspects (destruction and clean-up) in more detail.

\section{Lahar dynamic HEMUs}

Lahar studies tend to measure inundation depth when examining impacts, with dynamic pressure assessed based on field observations. With new numerical models in development (e.g., D-CLAW; Iverson et al., 2016), it seems likely that dynamic pressure will soon be an available output. However, much work has already been done tying inundation depth to damage and possible fatalities (e.g., Jenkins et al., 2015). We thus adopt two HEMUs for lahars: dynamic pressure in $\mathrm{kPa}$, and inundation depth in $\mathrm{m}$, both input as rasters. The user can also load a shapefile polygon denoting presence/absence; a default value of $5 \mathrm{kPa}$ and $2 \mathrm{~m}$ (inundation depth) is assigned to the polygon extent. For dynamic pressure, $5 \mathrm{kPa}$ is within range of inferred values observed at Merapi in Indonesia (Jenkins et al., 2015), whereas $2 \mathrm{~m}$ is on the low end of lahar inundation depths (Vallance and Iverson, 2015) but large enough to be lethal.

\section{Lahar static HEMUs}

Lahars cause damage during emplacement, and leave a deposit that may need to be cleaned up for area rehabilitation. For clean-up considerations, deposit depth is a key parameter. Although final deposit depth is almost always less than the event inundation depth, model outputs tend to be inundation depth, and so we use it at the clean-up HEMU as well, measured in metres, recognising it is likely an overestimate.

\section{Edifice}

Volcanic edifices, the structures around the volcanic vents, are included in RiskScape as AVF eruptions generally create a new cone, tuff ring, and/or maar. For many volcanoes around the world, specifically those with well-established edifices, the edifice itself does not create a hazard. However, as RiskScape was developed in New Zealand, the creation of new edifices in an Auckland eruption poses a serious hazard which needs to be included.

There is little research on the specific hazards of edifice formation, although it seems clear that the mere creation of a vent and edifice is extremely damaging. As such, we decided that presence/absence of the edifice is the most relevant HEMU. However, it may be that in the future there will be interest in removing or filling in edifices as recovery or other measures (e.g., many cones have been quarried in Auckland for building material), in which case a height value is useful. Consequently, RiskScape also uses a HEMU of height in metres, input as raster or a single polygon denoting edifice extent. Positive values correspond to built edifices (cones, tuff rings) and negative values to depressions (maars). In the case of a presence/absence polygon, the user specifies whether it is a cone or a caldera / maar; we arbitrarily assigned a default height of $+10 \mathrm{~m}$ and $-10 \mathrm{~m}$ to the entirety of the edifice for cone and caldera/maar, respectively.

\section{Asset module}

The asset module is required in RiskScape - this is an inventory of the elements at risk and their attributes (e.g., building height, roof pitch, daytime occupancy, road seal type). RiskScape can consider the following asset types: people, buildings, electricity cables, network junction points (e.g., transformers, switch/distribution boxes), pipelines (waste, potable, and storm water, and gas, oil, steam, and chemical pipelines), roads (including bridges), telecommunication cables, and waterways. A framework for agricultural assets is under development.

As people and vehicles are different from the other asset types in that they are mobile, in RiskScape they are allocated to buildings, with separate day and night time occupancy attributes for people derived from census data (see Cousins et al., 2014 for more information). At present, vulnerability functions for people and vehicles are tied to building damage state. In the non-volcanic hazards where this has been more fully developed, different functions are available for different situations, such as whether or not evacuation has been undertaken. A framework for allocating people to open spaces (e.g., streets, parks, beaches) rather than buildings is under development.

Each asset has a list of attribute fields; some are required for all assets (e.g., location information), others are required to apply a particular loss function in the vulnerability module. For example, to apply the vehicle 
reinstatement function in the vulnerability module for lahar, buildings must have the vehicle cost attribute filled in. For most functions in the vulnerability module however, vehicle cost is not an input variable and so is not required. At present given how basic much of the volcano vulnerability module is (see next section), the key attribute is location. The number of required attributes will increase as we input more sophisticated models.

RiskScape also has an asset modification tool. This allows the user to change asset attributes - e.g., the attributes of all buildings can be changed to meet a building code standard. The user can thus explore the effects of implementing and/or enforcing various policy measures.

Several asset libraries are pre-loaded in RiskScape, including building inventory for the Auckland and Hawkes Bay regions in New Zealand; all others need to be provided by the user. It is our experience that asset library curation is one of the most time-consuming aspects of overall preparation.

For details on the requirements of the asset module, see King and Bell (2009), Schimdt et al. (2011), and documentation within the RiskScape programme.

\section{Vulnerability module}

RiskScape provides a comprehensive suite of vulnerability and fragility functions (Table 2; referred to as 'Loss Types' in the RiskScape manual) for buildings, infrastructure, and people (assigned to buildings). A vulnerability function is either an index or percentage of damage normalised to complete destruction (e.g., $50 \%$ damage), the total cost of repair or replacement (damage cost), or a ratio of repair cost to value (damage ratio) as a function of HEMU (Tarbotton et al., 2015; a damage ratio is the ratio of). This definition of damage ratio is useful for economic loss calculations. To apply these models for insurance applications, consideration of policy conditions must be included. For example, often above damage ratios of $\sim 70 \%$ the asset is written off as there is too much uncertainty in repairing it. In these cases, a vulnerability function would jump to $100 \%$ loss at this threshold. A fragility function is the probability that a certain impact state will be exceeded given a particular HEMU (Rossetto et al., 2013; Tarbotten et al., 2015).

Some of the outputs listed in Table 2 are directly calculated with a function of HEMU and asset attribute(s) - this is the case for damage state and often damage ratio. Other outputs are a function of either damage state or damage ratio - this is the case for human susceptibility and human displacement. Whether an output is directly a function of HEMU and asset attributes or is rather a function of damage state or ratio depends on the quantity and quality of available data to develop these functions.

For volcanic hazards most of the vulnerability module is primitive in nature (i.e., binary functions). Many are drawn from Wilson et al. (2014) and Maqsood et al. (2013). We acknowledge these are basic - these are intended as a first step to be able to crudely compare volcanic to other hazards, and will be more sophisticated in future. The volcano vulnerability module doesn't yet model clean-up, consider compounding or cascading hazards, or treat infrastructure with much sophistication. We intend to add a probabilistic component, where the 'result' of an impact can differ between different runs reflecting both aleatoric and epistemic uncertainty; this is currently done for some of the other hazards in RiskScape such as earthquakes. It is also intended that in the future RiskScape users will be able load their own functions in for analysis.

A brief word on damage states is warranted. As RiskScape is a multi-hazard tool, the RiskScape team uses a common six-level damage state scale for all hazards $(0-5)$ for buildings, primarily based on levels of non-structural and structural damage (Table 3). Consequently, not all damage states are appropriate for all hazards, but this feature allows for more direct comparison across the hazards. A common multi-hazard damage state scale hasn't yet been established for infrastructure, so for the volcano module we have adapted them based on the general descriptions for buildings. We have drawn on existing work by Blong et al. (2003), Baxter et al. (2005), Jenkins et al. (2014b), Wilson et al. (2014), and Jenkins et al. (2015).

At present, RiskScape is solely concerned with groundbased impacts, and does not consider effects from ash disruption to the aviation industry.

In what follows we briefly describe the vulnerability modules in RiskScape; we emphasise this is a starting point and the intent is to update them within the next 5 years as needed.

\section{Volcanic ashfall}

For building volcanic ashfall damage ratio functions, RiskScape applies Maqsood et al. (2013) curves developed for the 2015 UN Global Assessment of Risk report (GAR15). These functions provide the damage ratio. The building typologies in Maqsood et al. (2013) were matched to the relevant New Zealand building stock types, and then were assigned one of the RiskScape building construction types (Table 4). Consequently, the two required attributes are location and building construction type. For building volcanic ashfall damage states (Table 3), we adapted the scales in Blong (2003) and Jenkins et al. (2014b).

Loss functions are in development for other asset types. Models for clean-up (e.g., Hayes et al., 2017a) are 
Table 2 Loss types supported by RiskScape for all perils

\begin{tabular}{|c|c|c|}
\hline Function type & Description & Possible states / values \\
\hline Damage state & $\begin{array}{l}\text { The extent to which } \\
\text { the asset is damaged. }\end{array}$ & See Table 3 \\
\hline Exposed state & $\begin{array}{l}\text { Whether or not an asset } \\
\text { is exposed to the hazard }\end{array}$ & $\begin{array}{l}\text {-1 - Unknown: Outside of the modelled area } \\
0 \text { - Not exposed: Inside the modelled area but } \\
\text { hazard indicates zero intensity } \\
1 \text { - Exposed: Inside the modelled area and greater } \\
\text { than zero hazard intensity }\end{array}$ \\
\hline
\end{tabular}

Functional downtime Productive time lost due to the impact of the hazard on the asset.
Human displacement A measure of the extent to which humans and human activities are displaced by exposure of the asse to the hazard.

Human losses

Human susceptibility The susceptibility to injury of a hypothetical human present in or at this asset

Reinstatement cost

Encompasses all direct costs caused by exposure of the asset to the hazard
0 - None: No or minimal evacuation necessary (less than 1 day).

1 - One day to 1 week: Evacuation necessary but reoccupation possible after less than a week. 2 - One week to 1 month: Evacuation necessary and reoccupation not possible for between a week and a month.

3 - One month to 6 months: Evacuation necessary and reoccupation not possible for between 1 and 6 months. 4 - Greater than 6 months: Evacuation necessary and reoccupation not possible for more than 6 months.

No or light injury: The person is either uninjured or only injured in ways that can be treated without trained medical assistance.

Moderate injury: The person is injured such that they require expert treatment (paraprofessional or doctor), but which are not immediately life threatening if such treatment is not available

Serious injury: The person is injured such that they require a greater degree of medical care and use of medical technology such as $\mathrm{x}$-rays or surgery, but not expected to progress to a life threatening status, full recovery expected with suitable treatment.

Critical injury: The person sustains injuries that pose an immediate life threatening condition if not treated adequately and expeditiously, or long-term disability. Dead: The person sustains injuries leading to immediate death.

0 - Insignificant: The hazard will not threaten anyone; only those who deliberately put themselves at risk are susceptible to injury.

1 - Low: Only those caught in exceptional circumstances are susceptible to injury.

2 - Medium: Only the most vulnerable are directly susceptible to injury.

3 - High: Those who can move to a protective environment are unlikely to be susceptible to injury but others will be. 4 - Extreme: Even fit able-bodied people are highly likely to be susceptible to injury

Asset Repair Cost: Costs incurred in restoring the asset to its pre-event state

Contents Repair Cost: Costs incurred in returning the contents (if any) of the asset to their pre-exposure state
Possible asset types

- Buildings

- Electricity cables

- Network junction point

- Pipelines

- Roads

- Telecommunication

cables

- Waterways

All

- Buildings

- Electricity cables

- Network junction point

- Pipelines

- Roads

- Telecommunication

cables

- Waterways

Buildings (people are assigned to buildings, with day and night-time occupancy rates as one of the building attribute types)

Buildings (people are assigned to buildings, with day and night-time occupancy rates as one of the building attribute types)

Buildings (people are assigned to buildings, with day and night-time occupancy rates as one of the building attribute types)

- Buildings

- Electricity cables

- Network junction point

- Pipelines 
Table 2 Loss types supported by RiskScape for all perils (Continued)

\begin{tabular}{|c|c|c|c|}
\hline Function type & Description & Possible states / values & Possible asset types \\
\hline & & $\begin{array}{l}\text { Services Repair Cost: Costs incurred in returning the services } \\
\text { (if any) of the asset to their pre-exposure state } \\
\text { Plant Repair Cost: Costs incurred in returning the plant } \\
\text { (if any) of the asset to their pre-exposure state } \\
\text { Stock Replacement Cost: Costs incurred in returning the stock } \\
\text { (if any) held at the asset to their pre-exposure state } \\
\text { Cleanup Cost: Costs incurred for necessary demolition, } \\
\text { and/or removing debris, silt, effluent etc. from an asset } \\
\text { Disruption Cost: Costs incurred due to the disruption } \\
\text { of activities usually conducted in the asset } \\
\text { Vehicle Cost: Costs incurred due to the damage } \\
\text { of vehicles located at the asset }\end{array}$ & $\begin{array}{l}\text { - Roads } \\
\text { - Telecommunication } \\
\text { cables } \\
\text { - Waterways }\end{array}$ \\
\hline
\end{tabular}

yet to be implemented either for volcanic ashfall or for pyroclastic density current.

\section{Flow hazards}

The three flow hazards (PDCs, lahars, and lava flows) are presently treated similarly for the RiskScape vulnerability module. This serves as a starting point prior to the development of more advanced function. For all three, RiskScape applies the thresholds proposed in Wilson et al. (2014); these are binary for lahar and lava flow. At present RiskScape assumes that buried assets (e.g., buried pipes) are not damaged by the three flow hazards. Below we summarise hazard-specific considerations for the vulnerability module.

\section{Pyroclastic density currents}

The Wilson et al. (2014) thresholds are matched to damage state, and expert judgment translated these to damage ratio (Table 5). All non-building, non-buried assets exposed to PDC are assumed destroyed. For damage states (Table 3), we have adapted the scale proposed in Baxter et al. (2005), first presented in Spence et al. (2004).

\section{Lava flow}

We assume Damage State 5 (complete destruction) is reached for any building or non-buried asset (Tables 3 and 5).

\section{Lahar}

RiskScape applied a building damage scale based on Jenkins et al. (2015), although at present the function assumes that if there is any exposure (including to nonburied non-building assets), then damage is complete at Damage State 5 (Table 5; i.e., a binary function) - we intend to improve this in the future.

\section{Edifice}

RiskScape applies an absolute binary impact function for all assets (subarieal and buried) exposed to the creation of a volcanic edifice (including "negative" edifices such as maars): if there is no exposure, there is no loss, if there is exposure there is complete loss / death. We note that apart from the initial explosion, death by edifice construction is unlikely due to evacuation - building occupancy rates may need to be modified to reflect evacuation circumstances. Damage State 5 is assigned to exposed assets (Tables 3 and 5), indicating collapse and structural integrity failure of the asset. Current functions assume there will be no clean-up or reinstatement of assets built where the edifice was constructed, but this assumption may change with future research. We have thus future-proofed RiskScape by providing a mechanism for incorporating more refined functions in the future.

\section{Case study: A hypothetical Auckland volcanic field eruption}

To demonstrate how RiskScape's volcano module can be applied, we present an example evaluating the consequences of an Auckland Volcanic Field (AVF) eruption on the residential housing stock. An AVF eruption is of great concern to New Zealand as Auckland is home to one third of New Zealanders and is the country's economic hub.

The AVF has had at least 53 eruptions in the last $190 \mathrm{ka}$ (Leonard et al., 2017), with the last eruption 550 yBP (Needham et al., 2011). However, the rate of eruptions isn't constant, with notable periods of temporal clustering: half of the known eruptions happened in the last $60 \mathrm{ka}$, with a temporal clustering of eruptions around $30 \mathrm{ka}$ (Lindsay et al., 2011). For crosshazard comparative purposes, the recurrence rate is between 500 and 20,000 years (Molloy et al., 2009). A further challenge is that there are no definitive spatial or volumetric trend for the location or size of AVF eruptions (e.g., Bebbington and Cronin, 2011; Le Corvec et al., 2013; Bebbington, 2015).

The majority of AVF volcanoes are considered monogenetic. Eruptive activity generally included cone, tuff ring, or maar formation, a pyroclastic surge, an explosive 


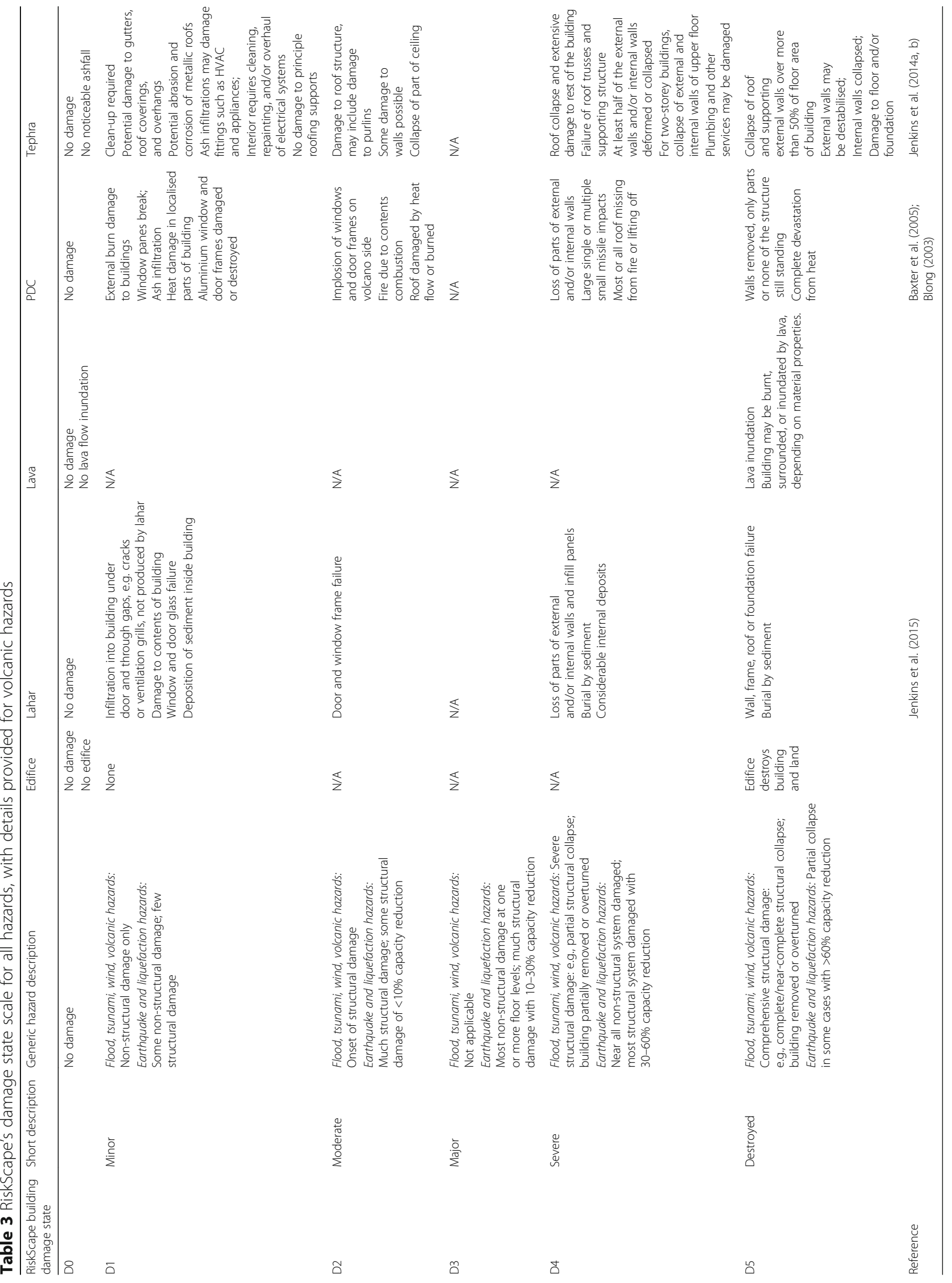


Table 4 Mapping of RiskScape building constructin type categories to Maqsood et al. (2014) building typologies

\begin{tabular}{|c|c|c|c|}
\hline $\begin{array}{l}\text { RiskScape Building Asset } \\
\text { Category }\end{array}$ & RiskScape Description & GAR Identifier & GAR Building Typology \\
\hline Construction Type $(1,2)$ & $\begin{array}{l}\text { 1: Reinforced concrete shear wall } \\
\text { 2: Reinforced concrete moment resisting frame }\end{array}$ & $\mathrm{A} 11$ & $\begin{array}{l}\text { Concrete Frame/Reinforced Masonry, non-engineered, } \\
\text { low rise, medium roof pitch }\end{array}$ \\
\hline Construction Type $(4,10)$ & $\begin{array}{l}\text { 4: Steel moment resisting frame } \\
\text { 10: Concrete masonry }\end{array}$ & A29 & $\begin{array}{l}\text { Concrete Frame with Unreinforced Masonry Infill Walls / } \\
\text { Steel Moment Frame, engineered, low rise, low roof pitch }\end{array}$ \\
\hline Construction Type (5) & Light timber & $A 2$ & $\begin{array}{l}\text { Light timber frame, engineered, low rise, } \\
\text { medium roof pitch }\end{array}$ \\
\hline Construction Type (9) & Brick masonry & A21 & $\begin{array}{l}\text { Unreinforced Masonry Bearing Walls, non-engineered, } \\
\text { low rise, medium roof pitch }\end{array}$ \\
\hline Construction Type (11) & Unknown residential & A4 & $\begin{array}{l}\text { Light timber frame, non-engineered, low rise, } \\
\text { medium roof pitch }\end{array}$ \\
\hline
\end{tabular}

In the tephra loss function, the required attributes are building location and construction type

phase with some tephra dispersion, and a lava flow (see Kereszturi et al., 2014).

\section{Scenario description}

The AVF eruption scenario we input into RiskScape is the Māngere Bridge scenario presented in Deligne et al. (2017). The scenario continues 'Exercise Ruaumoko', an all-of-New Zealand (Tier 4) civil defence and emergency management exercise concerning the unrest leading to an AVF eruption (MCDEM, 2008); the vent location was thus set by this exercise and is of no particular significance beyond exercise requirements (Deligne et al., 2017). The Māngere Bridge scenario provides a hypothetical eruption sequence once the hypothetical eruption starts. General eruption characteristics are loosely based on analogous historic eruptions, in particular eruptions at Hekla and Grímsvötn (Iceland), Killauea (Hawai'i), Stromboli and Etna (Italy), Parícutin (Mexico) and Spurr (Alaska). The scenario includes hazard layer shapefiles, which we here input into RiskScape; no on-the-fly modelling was done

Table 5 RiskScape damage state and damage ratio functions for all building types for non-tephra volcanic hazards

\begin{tabular}{lllll}
\hline Hazard & HIM & $\begin{array}{l}\text { Hazard } \\
\text { intensity }\end{array}$ & Damage State & $\begin{array}{l}\text { Damage } \\
\text { Ratio }\end{array}$ \\
\hline PDC & Dynamic pressure (kPa) & $<1$ & 0 & 0 \\
& & $1-10$ & 2 & 0.6 \\
& & $10-25$ & 4 & 0.75 \\
& & $>25$ & 5 & 1 \\
Lava & Thickness (m) & 0 & 0 & 0 \\
& & $>0$ & 5 & 1 \\
Lahar & Dynamic pressure (kPa) & 0 & 0 & 0 \\
& Or inundation depth (m) & $>0$ & 5 & 1 \\
Edifice & Height (m) & 0 & 0 & 0 \\
& & $\neq 0$ & 5 & 1 \\
\hline
\end{tabular}

In the tephra loss function, the required attributes are building location and construction type within the RiskScape program for this case study. Deligne et al. (2017) used the nearby prehistoric AVF Maungataketake eruption $(\sim 85-89 \mathrm{ka})$ as an analogue AVF eruption when developing hazard layers due to similar substrates and relative sea level (AgustínFlores et al., 2014).

Whilst the full scenario describes the temporal evolution of the hypothetical eruption (Deligne et al., 2017), here we focus solely on the final deposits (Fig. 3). We briefly describe how the hazard layers for the edifice, pyroclastic surge, tephra fall, and lava were generated; for more detail refer to Deligne et al. (2017).

\section{Edifice}

The edifice size is informed by the AVF Maungataketake eruption. The final edifice dimensions used for the Māngere Bridge scenario are a $1200 \mathrm{~m}$ diameter tuff ring with a nested cinder cone of $900 \mathrm{~m}$ diameter.

\section{Pyroclastic surge}

The Māngere Bridge scenario comprises three pyroclastic surge events, with two on the first day and one a week later (Deligne et al., 2017). The first surge is based on the "worse-case" scenario developed for the AVF for substrates similar to Maungataketake (e.g., location of Māngere Bridge scenario edifice) by Brand et al. (2014). Brand et al. (2014) suggested near complete destruction within $2.5 \mathrm{~km}$ of the vent (> $35 \mathrm{kPa}$ dynamic pressure), severe damage between 2.5 and $4 \mathrm{~km}$ of the vent (> $15 \mathrm{kPa}$ ), and moderate (for reinforced structures) to some (for weaker structures) damage between 4 and $6 \mathrm{~km}$ of the vent $(<5 \mathrm{kPa})$. The effect of directionality or topography is ignored for simplicity: it is likely the hazard layers overestimate hazard intensity and resulting damage. The latter two surges of the scenario are 'average' (smaller) surges in Brand et al. (2014) and consequently don't cause further damage. 


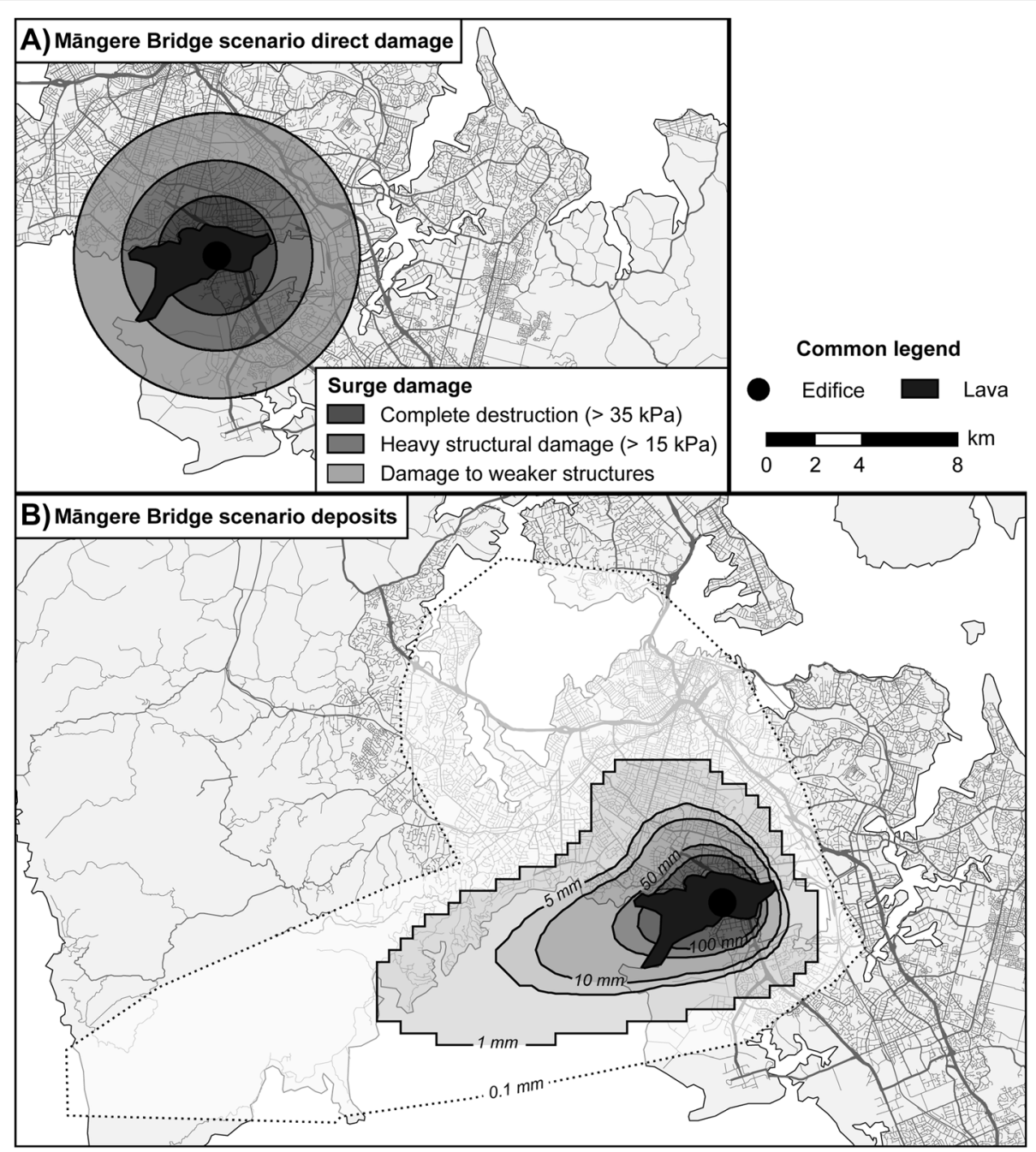

Fig. 3 Cumulative hazards of the Māngere Bridge scenario. a Damage caused by the creation of the edifice, the surge, lava, and ballistics according to level of destruction. $\mathbf{b}$ The cumulative deposit (assuming no cleaning or remobilisation) from the construction of the edifice, lava, the surge, and tephra fall. Roads are shown as a proxy for population density, with road thickness corresponding to road importance. Modified from Deligne et al. (2017)

\section{Volcanic ashfall deposit}

Rather than using RiskScape's on the fly modelling, in this scenario volcanic ashfall was modelled externally using TEPHRA2 (Bonadonna et al. 2005, Bonadonna et al. 2010) release 149, with the final raster then being uploaded into RiskScape. The total mass modelled for the Māngere Bridge scenario is $1.8 \times 10^{10} \mathrm{~kg}$, divided into four dispersion events modelled separately using daily wind for the scenario date in 2014 (see Deligne et al., 2017 for further details). For this exercise, we only consider the final cumulative deposit.

\section{Lava}

The lava layer is not based on modelling: the flow is centred about the Māngere Bridge scenario edifice, has a flow depth of $10 \mathrm{~m}$ (a mid-range AVF lava thickness according to Kereszturi et al. (2012)), does not inundate areas $>10 \mathrm{~m}$ above sea level, and cuts off the Manukau Inlet. The lava flow volume is $1 \times 10^{8} \mathrm{~m}^{3}$ - an order of magnitude more than the tephra volume and credible for $10 \mathrm{~m}$ thick AVF lavas (Kereszturi et al., 2012). This corresponds to an area of $10 \mathrm{~km}^{2}$. As it is not based on lava flow modelling, the hazard layer ignores effects of lava flow/water interactions, lava flow rheology, and finer scale topographic influences. These factors could serve to impede or focus lava flow advance. However, it is unlikely that a lava flow originating in the area of the Manngere Bridge scenario edifice would overtop the considerable topographic barriers directly north and northwest of the hypothetical scenario.

\section{Asset data}

For this scenario an exposure model consisting of residential buildings and contents was used to estimate 
losses to the residential housing sector. The exposure model was supplied by the New Zealand Earthquake Commission (EQC) which insures residential properties for losses from earthquake, volcanic activity, tsunami and landslides. The exposure database has building level information, including the construction type (used in the vulnerability module; Table 4), replacement value and other characteristics.

For the Auckland region, the residential housing stock has a building replacement value of NZ\$108BN, and a contents replacement value of NZ\$26.4BN. For the area affected by the eruption, defined as the limit of tephra deposition, the value of buildings is $\$ 40.31 \mathrm{BN}$ and contents is $\$ 10.08 \mathrm{BN}$.

\section{Volcanic eruption loss calculation}

Ground-up losses to residential buildings and contents for the Māngere Bridge scenario were calculated by estimating the loss per property for each of the volcanic hazards according to the eruption scenario. The maximum loss across all hazards was assigned as the loss for that property for the whole scenario and then losses were summed across the portfolio. In other words, for any given building, loss was calculated assuming only edifice exposure, then only volcanic ashfall exposure, then only PDC exposure, and finally only lava flow exposure. The loss value due to the hazard which caused the greatest loss is taken as the loss attributed to that building. This approach does not 'double count' losses incurred from each hazard, but a limitation is that it does not consider conditional vulnerabilities from the sequence of volcanic hazard events (e.g., buildings weakened, but not destroyed, by PDC impact which are then subjected to tephra fall loading).

Additional loss functions were created to examine contents damage by using expert judgement to tie building state (for volcanic ashfall, deposit thickness was used instead) to contents damage (Table 6). Contents include non-structural elements, such as gutters or heating, air conditioning, or ventilation systems. For tephra, the thresholds identified in Wilson et al. (2014) were applied using expert judgement. These contents damage functions are not currently within the core RiskScape software programme.

\section{Loss calculation results}

A total of 139,900 properties are in the area affected by the Māngere Bridge volcanic eruption scenario, defined as the limit of volcanic ashfall deposit (Fig. 4). The estimated losses for this scenario are NZ\$6600 M for residential buildings and NZ\$2100 $\mathrm{M}$ for residential contents, giving a total estimate scenario loss of NZ\$8700 M. The losses are dominated by the pyroclastic surge event ( $85 \%$ of the gross loss) which causes
Table 6 Māngere Bridge scenario state contents damage ratio (not currently in RiskScape)

\begin{tabular}{|c|c|c|c|}
\hline Hazard & $\begin{array}{l}\text { Building Damage } \\
\text { State }\end{array}$ & $\begin{array}{l}\text { Tephra thickness } \\
(\mathrm{mm})\end{array}$ & $\begin{array}{l}\text { Contents Damage } \\
\text { Ratio }\end{array}$ \\
\hline \multirow[t]{2}{*}{ Edifice } & 0 & - & 0 \\
\hline & 5 & & 1 \\
\hline \multirow[t]{4}{*}{ PDC } & 0 & - & 0 \\
\hline & 2 & & 0.6 \\
\hline & 4 & & 1 \\
\hline & 5 & & 1 \\
\hline \multirow[t]{2}{*}{ Lava } & 0 & - & 0 \\
\hline & 5 & & 1 \\
\hline \multirow[t]{4}{*}{ Volcanic ashfall } & - & $<10$ & 0 \\
\hline & & $10-100$ & 0.3 \\
\hline & & $101-500$ & 0.7 \\
\hline & & $>500$ & 1 \\
\hline
\end{tabular}

near total loss for most hazard intensities. Around 10\% of the gross loss is from tephra and the remainder ( 5\%) from lava flows. The losses are highest in the vicinity of the edifice (Fig. 5), but losses are incurred in all areas affected by volcanic ash. There is not always a correlation between numbers of properties impacted and loss: areas with high average property values, such as the Mt. Roskill suburb have fewer properties, yet they experience greater total loss (Figs. 4 and 5).

\section{Scenario limitations}

Work undertaken by Deligne et al. (2017), Hayes et al. (2017a), and Blake et al. (2017) shows that the Māngere Bridge scenario would be extremely disruptive to infrastructure and would have many economic repercussions. Indeed, the new edifice's dual proximity to the isthmus and industrial areas make it close to a worst-case scenario from an infrastructure and economics perspective, losses not calculated in this case study example. However, from the residential building stock viewpoint considered in this study, it is not a worst-case scenario - a worst case scenario would likely be on land closer to central Auckland where there is greater residential population density and higher value properties.

Uncertainty in the hazard and vulnerability modelling has not been explicitly treated in this scenario. Future work should include incorporating uncertainty in the vulnerability models and the hazard layers in order to allow quantification of the uncertainty in the loss estimates.

The losses are dominated by the pyroclastic surge event, which causes around $85 \%$ of the losses. The pyroclastic surge was considered to be a 'worst case' version of the hazard and does not include directionality or topographic effects. This will likely result in an overestimate of the hazard intensity, particular in its distal reaches, but may 


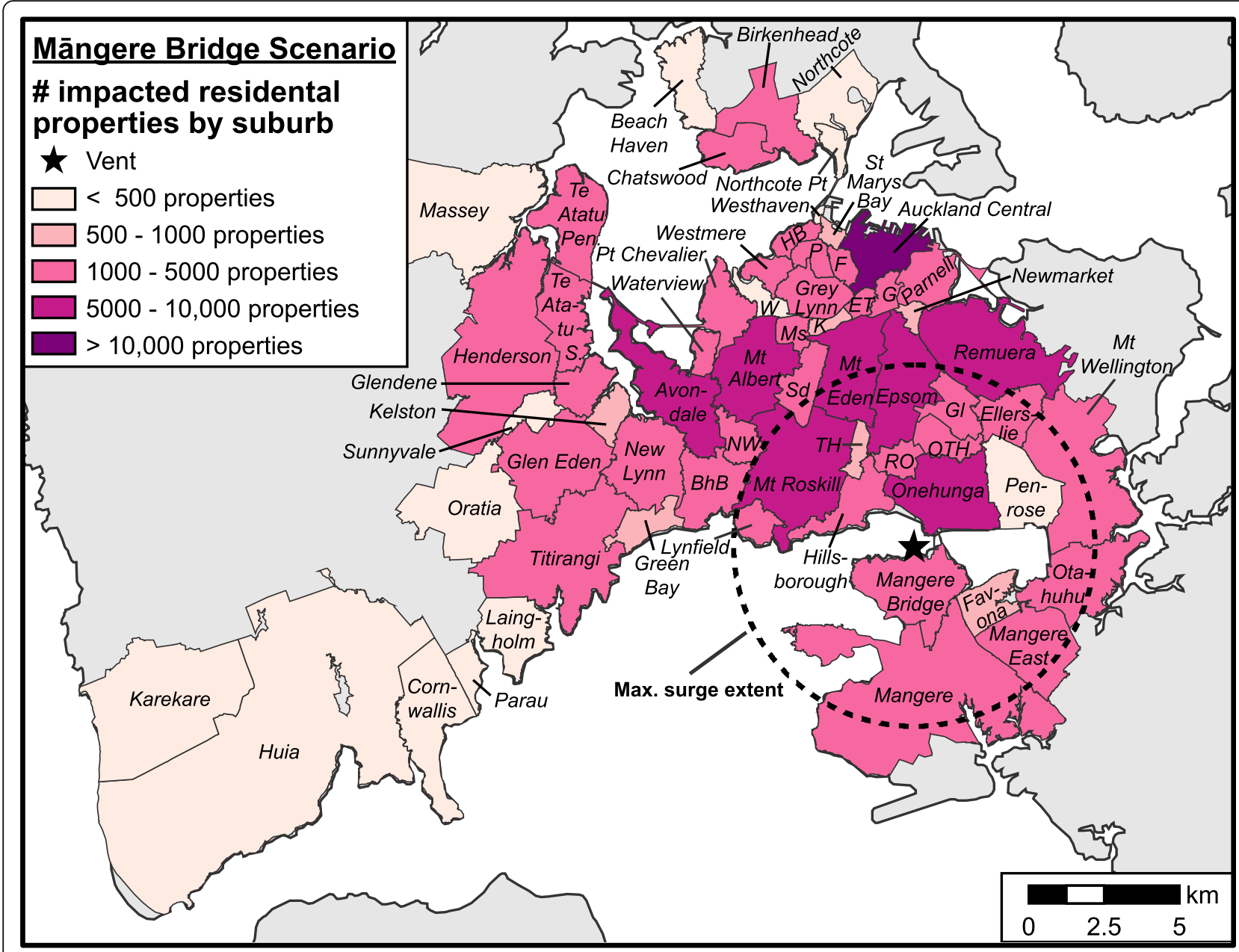

Fig. 4 Number of properties impacted by suburb for the Māngere Bridge scenario. All labelled suburbs have at least one property impacted. One building can have several properties (e.g., apartment buildings). The vent of the hypothetical Māngere Bridge scenario is shown with a green star, and the extent of the most severe surge is outlined (see Fig. 3). Suburb abbreviations: BhB - Blockhouse Bay; ET - Eden Terrace; F - Freemans Bay; G - Grafton; Gl - Greenlane; HB - Herne Bay; K - Kingsland; Ms. - Morningside; NW - New Windsor; OTH - One Tree Hill; P Ponsonby; SD - Sandringham; TH - Three Kings; W - Western Springs

underestimate the intensity in certain directions. Further work should develop pyroclastic surge scenarios taking into account directionality and topographic effects.

The Māngere Bridge scenario is one of many possible eruption outcomes for the AVF. The next eruption could be anywhere in the volcanic field, and will likely have a different eruption volume, duration, and hazard extents. This highlights one of the challenges of RiskScape, and, more broadly, risk assessment: the results rely on the quality and relevance of the input material. In the face of an uncertain hazard, it is helpful to pose a question appropriate given the tool. In this case, the question is "what sort of damages could be incurred by an AVF eruption" - an order of magnitude estimate was desired. A single scenario is a first step; we are working on developing a suite of scenarios across the AVF (Hayes et al., 2017b) which will allow for more robust exploration of AVF eruption outcomes.

\section{Case study: Comparing across hazards}

Since RiskScape is a multihazard tool, this allows the losses from one hazard to be compared to another hazard within the same modelling environment. This is useful as it creates the opportunity to assess and rank the impacts from various hazards and prioritise mitigation measures with loss modelling results from a common platform. A recent study that used RiskScape to estimate earthquake losses for Auckland (Cousins et al., 2014 ) is compared to the estimated volcanic losses presented here. Cousins et al. (2014) identified that the Wairoa North Fault (Fig. 2c) generates the largest losses for the Auckland region from all identified fault sources in the New Zealand Seismic Hazard Model (Stirling et al., 2012). This fault has an estimated average recurrence interval of 12,600 years - potentially an order of magnitude less frequent than an AVF eruption. Using 


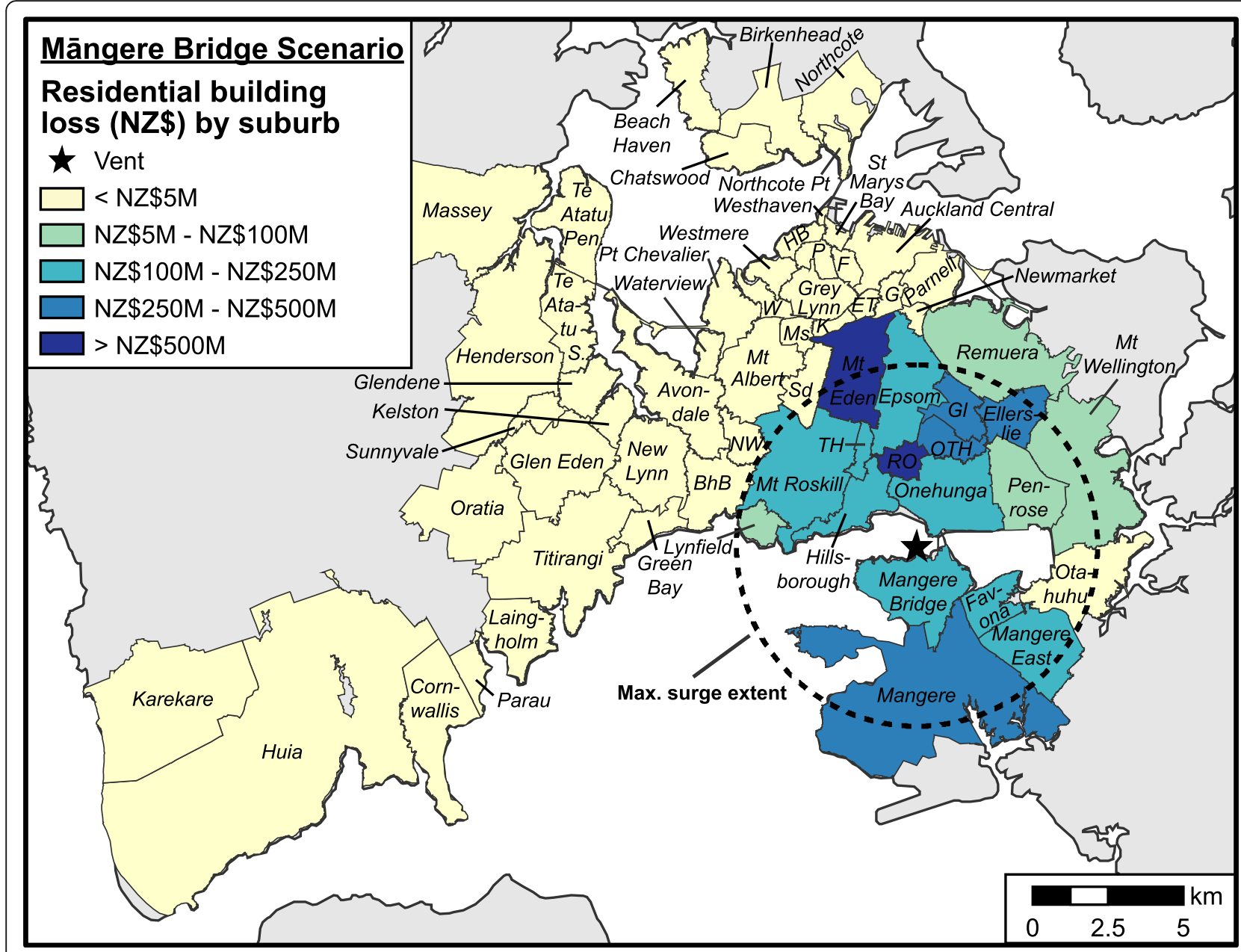

Fig. 5 Losses (NZ\$) by suburb for the Māngere Bridge scenario. All labelled suburbs experience loss. The vent of the hypothetical Māngere Bridge scenario is shown with a green star, and the extent of the most severe surge is outlined (see Fig. 3). For suburb abbreviations see Fig. 4 caption

the same residential building and contents portfolio as modelled in the Māngere Bridge volcanic eruption scenario, the estimated median losses to residential buildings and contents from the Wairoa North Fault are NZ\$2990 M.

This equates to around a third of the estimated losses from the Māngere Bridge eruption scenario (NZ\$8700 M). Thus, the earthquake fault source identified as likely to cause the greatest seismic impact to Auckland incurs considerably less damage than a less-than-worst-case scenario AVF eruption. As AVF eruptions are likely more frequent than a Wairoa North Fault earthquake, this is valuable information for making informed decisions on where research priorities and mitigative measures might be undertaken.

\section{Limitations}

We have presented the volcano module in RiskScape, and provided a sample application. We briefly discuss limitations of RiskScape, which in many cases are limitations faced by the wider risk assessment discipline.

A fundamental assumption in RiskScape is the three pronged approach - that hazard, assets, and vulnerability are considered independently. This is not per se a limitation, as it forms the foundation of most risk assessment, but is important to acknowledge.

Limitations may also arise from the final HEMU used. For example, damage ratios - the ratio of the cost of repair to the building replacement cost- are limited at 1 . This would omit instances from consideration where pre-emptive strengthening of a building is more expensive than the replacement value (a concern, for example, for some heritage structures).

A more pronounced limitation is that RiskScape solely considers damage to assets at the end of exposure. This is critical information, but is not the whole picture in terms of consequence to society. For example, RiskScape can be used to evaluate the damage suffered by a 
hospital or other critical site, but not how having a damaged hospital may strain resources at other hospitals due to increased workload. As such, it is important to understand when interpreting results that RiskScape evaluate damage, but at present not the implications of this damage.

Similarly, at present RiskScape does not allow directly consideration of time-varying or cascading impacts. This is perhaps less of an issue for some of the other hazards in RiskScape, but can be problematic for the multi-hazard events that are volcanic eruptions. However, most volcanic impact and risk studies around the world are currently focused on volcanic ash - one hazard of many - due to its widespread extent. This limitation only becomes a true limitation when assets are close enough to the vent to be exposed to more than one volcanic hazard. Likewise, if impacts are aggravated due to repeated or recurrent events - for example, a property damaged and repaired several times during an eruption sequence, rather than being damaged, and then repaired after the eruption sequence is complete - the current approach does not adequately capture the damage and associated loss.

RiskScape is a tool. The quality of the outputs relies on the quality and understanding of the inputs. The quality of the hazard module depends on the quality of the input rasters, which can encompass a large range of uncertainty. The asset module assumes a complete and sufficiently accurate asset inventory, which can be difficult to achieve. Finally, the vulnerability module relies on having adequate fragility and vulnerability functions. The volcano vulnerability module in Riskscape is currently basic with a strong bias towards a binary representation of volcanic hazards; this makes it more likely to overestimate the overall consequences of a hazardous event.

Despite these limitations, RiskScape is a useful tool - it allows for an objective, repeatable impact assessment. What we have presented is a starting point. As hazard models become more accurate errors due to the hazard module will decrease. The volcano vulnerability module will be improved to better incorporate uncertainty (e.g., through the use of fragility functions) and discretization of impact (rather than a purely binary approached) as appropriate.

\section{Conclusions}

RiskScape is a freely available multi-hazard loss assessment software programme. It has a modular structure, relying on hazard information, an asset inventory, and a suite of vulnerability and fragility functions. Five volcanic hazards are considered within RiskScape: volcanic ashfall, PDCs, lava flows, lahars, and edifice construction. We demonstrate how RiskScape can be applied to assess the impact of an AVF eruption (considering solely the residential building stock), and compare this to the impacts of the most damaging likely seismic event in Auckland.

\begin{abstract}
Abbreviations
AVF: Auckland Volcanic Field; BN: Billion; EQC: Earthquake Commission; GST: Goods and Services Tax; HEMU: Hazard Exposure Measurement Unit; HFA: Hyogo Framework for Action; ka: kiloannum (thousand years before present); KPa: kilopascals; M: Million; NIWA: National Institute of Water and Atmospheric Research; NZ: New Zealand; PDC: Pyroclastic Density Current; SFDRR: 2014-2030 Sendai Framework for Disaster Risk Reduction; yBP: years before present
\end{abstract}

\section{Acknowledgements}

This work benefited from conversations with Graham Leonard. We acknowledge internal GNS Science reviewer Tony Hurst. The manuscript was improved by suggestions from Russell Blong, an anonymous reviewer, and editor Susanna Jenkins.

\section{Funding}

The RiskScape programme is funded by the New Zealand Ministry of Business, Innovation, and Employment (MBIE). The Māngere Bridge scenario was developed with support from the Determining Volcanic Risk for Auckland (DEVORA) and Economics of Resilient Infrastructure (ERI) research programmes; DEVORA is funded by the Earthquake Commission (EQC) and Auckland Council (AC) and ERI is funded by MBIE. The Māngere Bridge scenario loss calculation was commissioned by the EQC.

\section{Authors' contributions}

NID, who has been overseeing the content of the volcano portion of RiskScape since 2012, selected hazard intensity measures for RiskScape, coordinated incorporation of volcanic vulnerability and fragility functions, developed hazard layers for the Māngere Bridge scenario, and drafted the majority of the manuscript. NH ran the Māngere Bridge scenario and Wairoa fault loss calculations and drafted some sections of the manuscript. SC and IM implemented RiskScape's volcano hazard and vulnerability modules. GW supported selection of HEMU and developed proximal hazard fragility functions. GTW adapted tephra fragility functions for New Zealand buildings. TMW oversaw fragility function development. All authors read and approved the final manuscript.

\section{Competing interests}

The authors declare they have no competing interest. RiskScape is freely available.

\section{Publisher's Note}

Springer Nature remains neutral with regard to jurisdictional claims in published maps and institutional affiliations.

\section{Author details \\ ${ }^{1}$ GNS Science, 1 Fairway Drive, Avalon, Lower Hutt 5010, New Zealand. ${ }^{2}$ Department of Geological Sciences, University of Canterbury, Private Bag 4800, Christchurch 8140, New Zealand. ${ }^{3}$ Earth Observatory of Singapore, Nanyang Technological University, 50 Nanyang Avenue, Block N2-01a-15, Singapore 639798, Singapore. ${ }^{4}$ Office of Emergency Management, 2 Havelock Street, West Perth, WA 6005, Australia.}

Received: 4 July 2016 Accepted: 1 November 2017 Published online: 02 December 2017

\section{References}

Agustín-Flores J, Németh K, Cronin SJ, Lindsay JM, Kereszturi G, Brand B, Smith IEM. Phreatomagmatic eruptions through unconsolidated coastal plain sequences, Maungataketake, Auckland volcanic field (New Zealand). J Volcanol Geotherm Res. 2014;276:46-63. 
Auker MR, Sparks RSJ, Siebert L, Crosweller HS, Ewert J. A statistical analysis of the global historical volcanic fatalities record. J Appl Volcanol. 2013;2(1):1-24.

Baxter PJ, Boyle R, Cole P, Neri A, Spence R, Zuccaro G. The impacts of pyroclastic surges on buildings at the eruption of the Soufrière Hills volcano, Montserrat. Bull Volcanol. 2005;67(4):292-313. https://doi.org/10. 1007/s00445-004-0365-7.

Baxter PJ, Neri A, Todesco M. Physical Modelling and human survival in Pyroclastic flows. Nat Hazards. 1998;17:163-76.

Bebbington MS. Spatio-volumetric hazard estimation in the Auckland volcanic field. Bull Volcanol. 2015;77(5):39. https://doi.org/10.1007/s00445-015-0921-3.

Bebbington MS, Cronin SJ. Spatio-temporal hazard estimation in the Auckland volcanic field, New Zealand, with a new event-order model. Bull Volcanol. 2011;73(1):55-72

Berryman KR (compiler) (2005) Review of tsunami hazard and risk in New Zealand. GNS Science Client Report 2005/104

Biass S, Frischknecht C, Bonadonna C. A fast GIS-based risk assessment for tephra fallout: the example of Cotopaxi volcano, Ecuador-part II: vulnerability and risk assessment. Nat Hazards. 2012;64:615-39. https://doi.org/10.1007/s11069012-0270-x

Blake DM, Deligne NI, Wilson TM, Lindsay JM, Grace ES, Woods R. Investigating the consequences of urban volcanism using a scenario approach II: insights into transportation network damage and functionality. J Volcanol Geotherm Res. 2017;340:92-116. https://doi.org/10.1016/j.jvolgeores.2017.04.010.

Blong RJ. Volcanic hazards: a sourcebook on the effects of eruptions. North Ryde, Australia: Academic Press; 1984.

Blong RJ. Building damage in Rabaul, Papua New Guinea. Bull Volcanol. 2003; 65(1):43-54.

Bonadonna C, Connor CB, Houghton BF, Connor L, Byrne M, Laing A, Hincks TK. Probabilistic modeling of tephra dispersal: hazard assessment of a multiphase rhyolitic eruption at Tarawera, New Zealand. J Geophys Res. 2005;110:03203.

Bonadonna C, Connor, LJ, Connor, CB, Courtland LM (2010) Tephra2. https:// vhub.org/resources/tephra2. Accessed 17 March 2016.

Bower SM, Woods AW. On the dispersal of clasts from volcanic craters during small explosive eruptions. J Volcanol Geoth Res. 1996:7319-32.

Brand BD, Gravley D, Clarke A, Lindsay J, Boomberg SH, Agustin-Flores J, Németh K. A combined field and numerical approach to understanding dilute pyroclastic density current dynamics and hazard potential: Auckland volcanic field, New Zealand. J Volcanol Geoth Res. 2014;276:215-32.

Cas RAF, Wright HMN, Folkes CB, Lesti C, Porreca M, Giordano G, Viramonte JG. The flow dynamics of an extremely large volume pyroclastic flow, the 2.08-ma Cerro Galán ignimbrite, NW Argentina, and comparison with other flow types. Bull Volcanol. 2011;73(10):1583-609. https://doi.org/10.1007/s00445-011-0564-y.

Cashman KV, Cronin SJ. Welcoming a monster: myths, oral tradition, and modern societal response to volcanic disasters. J Volcanol Geoth Res. 2008;176:407-18.

Cashman KV, Rust AC. Volcanic ash: generation and spatial variations. In: Mackie S, Cashman KV, Ricketts H, Rust AC, Watson IM, editors. Volcanic ash: hazard observation. Amsterdam: Elsevier; 2016. https://doi.org/10.1016/B978-0-08100405-0.00002-1.

Castruccio A, Rust AC, Sparks RSJ. Assessing lava flow evolution from post-eruption field data using Herschel-Bulkley rheology. J Volcanol Geoth Res. 2014;275:71-84.

Cole PD, Neri A, Baxter PJ. Hazards from Pyroclastic density currents. In: Sigurdsson H, Houghton B, McNutt S, Rymer H, Stix J, editors. Encyclopedia of volcanoes. 2nd ed. Amsterdam: Academic Press; 2015.

Cordonnier B, Lev E, Garel F (2015) Benchmarking lava-flow models. IN: Harris AJL, De Groeve T, Garel F, Carn SA (eds) Detecting, Modelling and Responding to Effusive Eruptions. Geological Society, London, Special Publications 426. doi: https://doi.org/10.1144/SP426.7.

Cousins WJ (2004) Towards a first-order earthquake loss model for New Zealand. In: Gregory G (ed) Getting the message across and moving ahead: New Zealand Society for Earthquake Engineering Conference 2004 Technical Papers, Wellington, New Zealand.

Cousins WJ, Nayyerloo M, Deligne NI (2014) Estimated damage and casualties from earthquakes affecting Auckland. GNS Science consultancy report 2013/324.

Cousins WJ, Power WL, Destegul U, King AB, Trevethick R, Blong R, Weir B, Miliauskas B (2009) Earthquake and tsunami losses from major earthquakes affecting the Wellington region. IN: Why do we still tolerate buildings that are unsafe in earthquakes: New Zealand Society for Earthquake Engineering 2009 Conference, 3-5 April, Christchurch, New Zealand.

Cousins WJ, Thomas G, Heron DW, Smith WD. Probabilistic modeling of postearthquake fire in wellington, New Zealand. Earthquake Spectra. 2012;28(2): 553-71. https://doi.org/10.1193/1.4000002.
Crosweller HS, Arora B, Brown SK, Cottrell E, Deligne NI, Guerrero NO, Hobbs L, Kiyosugi K, Loughlin SC, Lowndes J, Nayembil M, Siebert L, Sparks RSJ, Takarada S, Venzke E. Global database on large magnitude explosive volcanic eruptions (LaMEVE). J Appl Volcanol. 2012;1:4. https://doi.org/10.1186/21915040-1-4.

Deligne NI, Fitzgerald RH, Blake DM, Davies AJ, Hayes J, Stewart C, Wilson G, Wilson TM, Castelino R, Kennedy BM, Muspratt S, Woods R (2017). Investigating the consequences of urban volcanism using a scenario approach I: Development and application of a hypothetical eruption in the Auckland Volcanic Field, New Zealand. J Volcanol Geoth Res. doi: https://doi. org/10.1016/j.jvolgeores.2017.02.023.

Dioguardi F, Dellino P. PYFLOW: a computer code for the calculation of the impact parameters of dilute Pyroclastic density currents (DPDC) based on field data. Comput Geosci. 2014;66:200-10. https://doi.org/10.1016/j.cageo.2014.01.013.

Douglas J. Physical vulnerability modelling in natural hazard risk assessment. Nat Hazards Earth Syst Sci. 2007;7(2):283-8. https://doi.org/10.5194/nhess-7-283-2007.

Dowrick D, Cousins WJ, Rhoades DA (2004) Earthquake risk reduction in New Zealand. Proceedings of the World Conference of Earthquake Engineering (13th), paper 3464, Vancouver, Canada.

Dufek J, Esposti Ongaro T, Roche O. Pyroclastic density currents: processes and models. In: Sigurdsson H, Houghton B, McNutt S, Rymer H, Stix J, editors. Encyclopedia of volcanoes. 2nd ed. Amsterdam: Academic Press; 2015.

Esposti Ongaro T, Neri A, Todesco M, Macedonio G. Pyroclastic flow hazard assessment at Vesuvius (Italy) by using numerical modelling: II analysis of flow variables. Bull Volcanol. 2002;64(3-4):178-91. https://doi.org/10.1007/ s00445-001-0190-1.

Favalli M, Tarquini S, Fornaciai F, Boschi E. A new approach to risk assessment of lava flow at Mount Etna. Geology. 2009;37(12):1111-4. https://doi.org/10. 1130/G30187A.1.

Felpeto A, Araña V, Ortiz R, Astiz M, García A. Assessment and Modelling of lava flow hazard on Lanzarote (Canary Islands). Nat Hazards. 2001;23:247-57.

Fournier d'Albe EM. Objectives of volcanic monitoring and prediction. J Geol Soc Lond. 1979;136(3):321-6. https://doi.org/10.1144/gsjgs.136.3.0321.

Gehl P, Quinet C, Le Cozannet G, Kouokam E, Thierry P. Potential and limitations of risk scenario tools in volcanic areas through an example at Mount Cameroon. Nat Hazards Earth Syst Sci. 2013;13:2409-24. https://doi.org/10. 5194/nhess-13-2409-2013.

Gran KB, Montgomery DR, Halbur JC. Long-term elevated post-eruption sedimentation at mount Pinatubo, Philippines. Geology. 2011;39(4):367-70.

Gudmundsson MT. Hazards from lahars and Jökulhlaups. In: Sigurdsson H, Houghton B, McNutt S, Rymer H, Stix J, editors. Encyclopedia of volcanoes. 2nd ed. Amsterdam: Academic Press; 2015.

Harris AJL. Basaltic lava flow hazard. In: Papale P, editor. Volcanic hazards, risk and disasters. Amsterdam: Elsevier; 2015. https://doi.org/10.1016/B978-0-12396453-3.00002-2.

Hayes JL, Wilson TM, Deligne NI, Cole J, Hughes M. A model to assess tephra clean-up requirements in urban environments. J Appl Volcanol. 2017;6:1. https://doi.org/10.1186/s13617-016-0052-3.

Hayes JL, Wilson TM, Deligne NI, Leonard GS (2017) Embracing deep uncertainties and transparently developing plausible scenarios for volcanic impact and risk assessment. IAVCEI General Assembly, Portland, OR, USA, 14-18 August 2017.

Hayes JL, Wilson TM, Magill CR. Tephra fall clean-up in urban environments. J Volcanol Geoth Res. 2015;304:359-77. https://doi.org/10.1016/j.jvolgeores. 2015.09.014.

Horspool NA, Cousins WJ, Power WL (2015) Review of tsunami risk facing New Zealand: a 2015 update. GNS science consultancy report 2015/38.

Horwell CJ, Baxter PJ. The respiratory health hazards of volcanic ash: a review for volcanic risk mitigation. Bull Volcanol. 2006;69(1):1-24. https://doi.org/10. 1007/s00445-006-0052-y.

Hurst AW (1994) ASHFALL - A computer program for estimating volcanic ash fallout (Report and User Guide). GNS Science Report 1994/23.

Hurst AW, Smith W. A Monte Carlo methodology for modelling ash fall hazards. J Volcanol Geoth Res. 2004;132:393-403. https://doi.org/10.1016/j.jvolgeores. 2004.08.001.

Hurst AW, Smith W. Volcanic ashfall in New Zealand: probabilistic hazard modelling for multiple sources. N Z J Geol Geophys. 2010;53(1):1-14. https:// doi.org/10.1080/00288301003631129.

Iverson RM. The physics of debris flows. Reviews of Geophysics. 1997;35(3):245-96.

Iverson RM, George DL, Logan M. Debris flow runup on vertical barriers and adverse slopes. Journal of Geophysical Research: Earth Surface. 2016;121(12):2333-57. 
Jenkins S, Spence RJS, Fonseca JFBD, Solidum RU, Wilson TM. Volcanic risk assessment: quantifying physical vulnerability in the built environment. J Volcanol Geoth Res. 2014;276:105-20.

Jenkins SF, Day SJ, Faria BE, Fonseca JFBD (2017) Damage from lava flows: insights from the 2014-2015 eruption of Fogo, Cape Verde. J Appl Volcanol. 6:6. doi: https://doi.org/10.1186/s13617-017-0057-6.

Jenkins SF, Phillips JC, Price R, Feloy K, Baxter PJ, Hadmoko DS, de Bélizal E. Developing building-damage scales for lahars: application to Merapi volcano, Indonesia. Bull Volcanol. 2015;77(9):75. https://doi.org/10.1007/s00445-0150961-8.

Jenkins SF, Wilson TM, Magill C, Miller V, Stewart C, Marzocchi W, Bolton M (2014) Volcanic Ash Fall Hazard and Risk: Technical Background Paper for the UNISDR 2015 Global Assessment Report on Disaster Risk Reduction. Global Volcano Model and IAVCEl. https://www.unisdr.org/we/inform/publications/ 49769. Accessed 13 November 2017

Johnston D, Becker J, Jolly G, Potter S, Wilson TM, Stewart C, Cronin S (2011) Volcanic Hazards Management at Taranaki Volcano: Information Source Book. GNS Science Report, 2011/137.

Kereszturi G, Németh K, Cronin SJ, Procter JN, Agustín-Flores J. Influences on the variability of eruption sequences and style transitions in the Auckland volcanic field, New Zealand. J Volcanol Geoth Res. 2014;286:101-15.

Kereszturi G, Procter JN, Cronin SJ, Németh K, Bebbington MS, Lindsay JM. LiDARbased quantification of lava flow susceptibility in the City of Auckland (New Zealand). Remote Sens Environ. 2012;125:198-213.

Kilburn CRJ. Lava flow hazards and modeling. In: Sigurdsson H, Houghton B, McNutt S, Rymer H, Stix J, editors. Encyclopedia of volcanoes. 2nd ed. Amsterdam: Academic Press; 2015.

King A, Bell R (2009) RiskScape Project: 2004-2008. GNS Science Consultancy Report 2009/247.

Komorowski J-C, Jenkins S, Baxter PJ, Picquout A, Lavigne F, Charbonnier SJ, Gertisser R, Preece K, Cholik N, Budi-Santoso A, Surono (2013) Paroxysmal dome explosion during the Merapi 2010 eruption: processes and facies relationships of associated high-energy pyroclastic density currents. J Volcanol Geoth Res 261: 260-294. doi: https:/doi.org/10.1016/j.jvolgeores.2013.01.007.

Lavigne F. Lahar hazard micro-zonation and risk assessment in Yogyakarta city, Indonesia. GeoJournal. 1999;49:173-83.

Le Corvec N, Bebbington MS, Lindsay JM, McGee LE. Age, distance, and geochemical evolution within a monogenetic volcanic field: analyzing patterns in the Auckland volcanic field eruption sequence. Geochem Geophys Geosyst. 2013;14(9):3648-65.

Leonard GS, Calvert AT, Hopkins JL, Wilson CJN, Smid ER, Lindsay JM, Champion DE. High-precision 40Ar/39Ar dating of quaternary basalts from Auckland volcanic field, New Zealand, with implications for eruption rates and paleomagnetic correlations. J Volcanol Geoth Res. 2017;343:60-74. https:// doi.org/10.1016/j.jvolgeores.2017.05.033.

LGNZ (2014) Managing natural hazard risk in New Zealand - towards more resilient communities. A think piece for local and central government and others with a role in managing natural hazards. Local Government New Zealand. http://www.lgnz.co.nz/assets/Publications/Managing-naturalhazards-LGNZ-think-piece.pdf. Accessed 10 May 2016.

Lindsay JM, Leonard GS, Smid ER, Hayward BW. Age of the Auckland volcanic field: a review of existing data. N Z J Geol Geophys. 2011;54(4):379-401.

Lirer L, Petrosino P, Alberico I. Hazard and risk assessment in a complex multisource volcanic area: the example of the Campania region, Italy. Bull Volcanol. 2010;72(4):411-29.

Lirer L, Vitelli L. Volcanic risk assessment and mapping in the Vesuvian area using GIS. Nat Hazards. 1998;17:1-15

Loughlin SC, Sparks RSJ, Brown SK, Jenkins SF, Vye-Brown C, editors. Global volcanic hazards and risk. Cambridge, United Kingdom: Cambridge University Press; 2015.

Lube G, Cronin SJ, Platz T, Freundt A, Procter JN, Henderson C, Sheridan MF. Flow and deposition of pyroclastic granular flows: a type example from the 1975 Ngauruhoe eruption, New Zealand. J Volcanol Geoth Res. 2007;161(3): 165-86. https://doi.org/10.1016/j.jvolgeores.2006.12.003.

MacDonald GA. Pahoehoe, aa, and block lava. Am J Sci. 1953;251:169-91.

Macedonio G, Pareschi MT, Santacroce R. Renewal of volcanic activity at Vesuvius: tephra fallout. J Volcanol Geotherm Res. 1990;40(4):327-42. https://doi.org/10. 1016/0377-0273(90)90112-S.

Magill C, Blong R. Volcanic risk ranking for Auckland, New Zealand. I: methodology and hazard investigation. Bull Volcanol. 2005a;67(4):331-9. https://doi.org/10.1007/s00445-004-0374-6.
Magill C, Blong R. Volcanic risk ranking for Auckland, New Zealand. II: hazard consequences and risk calculation. Bull Volcanol. 2005b;67(4):340-9. https:// doi.org/10.1007/s00445-004-0375-5.

Maqsood ST, Wehner M, Ryu H, Edwards M, Dale K (2014) GAR15 Vulnerability Functions: Reporting on the UNISDR/GA SE Asian Regional Workshop on Structural Vulnerability Models for the GAR Global Risk Assessment, 11-14 November, 2013: Geoscience Australia, Canberra.

Marzocchi W, Garcia-Aristizabal A, Gasparini P, Mastellone ML, Di Ruocco A. Basic principles of multi-risk assessment: a case study in Italy. Nat Hazards. 2012; 62(2):551-73.

Mastin LG, Guffanti M, Ewert JW, Spiegel J (2009). Preliminary Spreadsheet of Eruption Source Parameters for Volcanoes of the World. United States Geological Survey Open-File Report 2009-1133, v. 1.2.

Mastin LG, Guffanti M, Servranckx R, Webley P, Barsotti S, Dean K, Durant A, Ewert JW, Neri A, Rose WI, Schneider D, Siebert L, Stunder B, Swanson G, Tupper A, Volentik A, Waythomas CF. A multidisciplinary effort to assign realistic source parameters to models of volcanic ash-cloud transport and dispersion during eruptions. J Volcanol Geotherm Res. 2009;186(1-2):10-21.

MCDEM (2008) Exercise Ruaumoko '08: Final Report. Ministry of Civil Defence and Emergency Management. https://web.archive.org/web/20130210012343 http://www.civildefence.govt.nz/memwebsite.nsf/Files/ National\%20Exercise\%20Programme/\$file/FINAL-REPORT-Aug08. Accessed 10 September 2015

Molloy C, Shane PAR, Augustinus P. Eruption recurrence rates in a basaltic volcanic field based on tephra layers in maar sediments: implications for hazards in the Auckland volcanic field. Geol Soc Am Bull. 2009;121(4):166677.

Needham AJ, Lindsay JM, Smith IEM, Augustinus P, Shane PAR. Sequential eruption of alkaline and sub-alkaline magmas from a small monogenetic volcano in the Auckland volcanic field, New Zealand. J Volcanol Geotherm Res. 2011;201(1-4):126-42.

Neri A, Ong E. Pyroclastic density current hazards and risk. In: Papale P, editor. Volcanic hazards, risk and disasters. Amsterdam: Elsevier; 2015. https://doi. org/10.1016/B978-0-12-396453-3.00005-8.

NIU (2015) The Thirty Year New Zealand Infrastructure Plan 2015. National Infrastructure Unit, New Zealand Treasury. Available from http://www. infrastructure.govt.nz/plan/2015/nip-aug15.pdf. Accessed 10 May 2016.

Panza GF, Irikura K, Kouteva M, Peresan A, Wang Z, Saragoni R. Advanced seismic hazard assessment. Pure Appl Geophys. 2011;168(1):1-9. https://doi.org/10. 1007/s00024-010-0179-9.

Patrick MR, Dehn J, Dean K. Numerical modeling of lava flow cooling applied to the 1997 Okmok eruption: approach and analysis. J Geophys Res. 2004;109: B03202. https://doi.org/10.1029/2003JB002537.

Patrick MR, Dehn J, Dean K. Numerical modeling of lava flow cooling applied to the 1997 Okmok eruption: comparison with advanced very high resolution radiometer thermal imagery. J Geophys Res. 2005;110:B02210. https://doi.org/ 10.1029/2003JB002538.

Pierson TP, Janda RJ, Thouret JC, Borerro CA. Perturbation and melting of snow and ice by the 13 November 1985 eruption of Nevado del Ruiz, Colombia, and consequent mobilization, flow and deposition of lahars. J Volcanol Geotherm Res. 1990;41:17-66.

Pomonis A, Spence R, Baxter P. Risk assessment of residential buildings for an eruption of Furnas volcano, São Miguel, the Azores. J Volcanol Geotherm Res. 1999;92(1-2):107-31. https://doi.org/10.1016/S0377-0273(99)00071-2.

Roche $\mathrm{O}$. Nature and velocity of pyroclastic density currents inferred from models of entrainment of substrate lithic clasts. Earth Planet Sci Lett. 2015; 418:115-25. https://doi.org/10.1016/j.epsl.2015.03.001.

Rossetto T, loannou I, Grant DN. Existing empirical vulnerability and fragility functions: compendium and guide for selection. GEM technical report 2013X. Pavia, Italy: GEM Foundation; 2013.

Schilling S (1998) LAHARZ: GIS programs for automated mapping of lahar-inundation hazard zones. United States Geological Survey Open-File Report 98-638.

Schmidt J, Matcham I, Reese S, King A, Bell R, Henderson R, Smart G, Cousins WJ, Smith W, Heron DW. Quantitative multi-risk analysis for natural hazards: a framework for multi-risk modelling. Nat Hazards. 2011;58(3):1169-92. https:// doi.org/10.1007/s11069-011-9721-z.

Self S, RSJ S, Booth B, GPL W. The 1973 Heimaey Strombolian scoria deposit, Iceland. Geol Mag. 1974;111:539-48.

Sigurdsson H. Introduction. In: Sigurdsson H, Houghton B, McNutt S, Rymer H, Stix J, editors. Encyclopedia of volcanoes. 2nd ed. Amsterdam: Academic Press; 2015. 
Spence RJS, Baxter PJ, Zuccaro G. Building vulnerability and human casualty estimation for a pyroclastic flow: a model and its application to Vesuvius. J Volcanol Geoth Res. 2004;133(1-4):321-43.

Spence RJS, Kelman I, Baxter PJ, Zuccaro G, Petrazzuoli S. Residential building and occupant vulnerability to tephra fall. Nat Hazards Earth Syst Sci. 2005a;5(4): 477-94.

Spence RJS, Kelman I, Calogero E, Toyos GP, Baxter PJ, Komorowski J-C. Modelling expected physical impacts and human casualties from explosive volcanic eruptions. Nat Hazards Earth Syst Sci. 2005b;5(6):1003-15. https://doi. org/10.5194/nhess-5-1003-2005.

Spence RJS, Kelman I, Brown A, Toyos GP, Purser D, Baxter PJ. Residential building and occupant vulnerability to pyroclastic density currents in explosive eruptions. Nat Hazards Earth Syst Sci. 2007;7(2):219-30. https://doi org/10.5194/nhess-7-219-2007.

Stewart C, Pizzolon L, Wilson TM, Leonard GS, Dewar D, Johnston DM, Cronin SJ. Can volcanic ash poison water supplies? Integr Environ Assess Manag. 2009; 5(4):713-6.

Stirling MW, McVerry GH, Gerstenberger MC, Litchfield NJ, Van Dissen RJ, Berryman KR, Barnes P, Beavan RJ, Bradley B, Clark KJ, Jacobs K, Lamarche G, Langridge RM, Nicol A, Nodder S, Pettinga J, Reyners ME, Rhoades DA, Smith WD, Villamor P, Wallace LM. National seismic hazard model for New Zealand: 2010 update. Bull Seismol Soc Am. 2012;102:1514-42.

Tarbotton C, Dall'Osso F, Dominey-Howes D, Goff J. The use of empirical vulnerability functions to assess the response of buildings to tsunami impact: comparative review and summary of best practice. Earth Sci Rev. 2015;142: 120-34. https://doi.org/10.1016/j.earscirev.2015.01.002.

Thierry P, Stieltjes L, Kouokam E, Nguéya P, Salley PM. Multi-hazard risk mapping and assessment on an active volcano: the GRINP project at Mount Cameroon. Nat Hazards. 2008;45(3):429-56.

Thomas G, Heron DW, Cousins WJ, de Roiste M. Modeling and estimating postearthquake fire spread. Earthquake Spectra. 2012;28(2):795-810. https://doi. org/10.1193/1.4000009.

Trusdell FA (1995) Lava flow hazards and risk assessment on Mauna Loa volcano Hawaii. In: Rhodes JM, Lockwood JP (eds) Mauna Loa Revealed: Structure, Composition, History, and Hazards. Geophys. Mon. 92. American Geophysical Union, Washington DC.

United Nations (2015) Sendai Framework for Disaster Risk Reduction 2015-2020. http://www.unisdr.org/files/43291_sendaiframeworkfordrren.pdf. Accessed 24 April 2016.

Valentine G. Damage to structures by pyroclastic flows and surges, inferred from nuclear weapons effects. J Volcanol Geoth Res. 1998:87(1-4):117-40. https:// doi.org/10.1016/50377-0273(98)00094-8.

Vallance JW, Iverson RM. Lahars and their deposits. In: Sigurdsson H, Houghton B, McNutt S, Rymer H, Stix J, editors. Encyclopedia of volcanoes. 2nd ed. Amsterdam: Academic Press; 2015.

Vicari A, Alexis H, Del Negro C, Coltelli M, Marsella M, Proietti C. Modeling of the 2001 lava flow at Etna volcano by a cellular automata approach. Environ Model Softw. 2007;22(10):1465-71.

Volentik ACM, Bonadonna C, Connor CB, Connor L, Rosi M. Modeling tephra dispersal in absence of wind: insights from the climactic phase of the 2450 BP Plinian eruption of Pululagua volcano (Ecuador). J Volcanol Geoth Res. 2010;193:117-36. https://doi.org/10.1016/j.jvolgeores.2010.03.011.

Walker GPL (1981). The Waimiha and Hatepe plinian deposits from the rhyolitic Taupo volcanic Centre. N Z J Geol Geophys 24: 305-324.

Wardman JB, Wilson TM, Bodger PS, Cole JW, Stewart C. Potential impacts from tephra fall to electric power systems: a review and mitigation strategies. Bull Volcanol. 2012;74(10):2221-41.

Widiwijayanti C, Voight B, Hidayat D, Schilling SP. Objective rapid delineation of areas at risk from block-and-ash pyroclastic flows and surges. Bull Volcanol. 2009;71:687. https://doi.org/10.1007/s00445-008-0254-6.

Wilson G, Wilson TM, Deligne NI, Cole JW. Volcanic hazard impacts to critical infrastructure: a review. J Volcanol Geotherm Res. 2014;286:148-82.

Wilson TM, Jenkins S, Stewart C. Impacts from volcanic ash fall. In: Papale P, editor. Volcanic hazards, risk and disasters. Amsterdam: Elsevier; 2015. https:// doi.org/10.1016/B978-0-12-396453-3.00003-4.

Wilson TM, Stewart C, Sword-Daniels V, Leonard G, Johnston DM, Cole JW, Wardma J, Wilson G, Barnard S. Volcanic ash impacts on critical infrastructure. Phys Chem Earth Part A/B/C. 2012:45-46:5-23.

Zuccaro G, Cacace F, Spence RJS, Baxter PJ. Impact of explosive eruption scenarios at Vesuvius. J Volcanol Geotherm Res. 2008;178(3):416-53. https:// doi.org/10.1016/j.jvolgeores.2008.01.005.

\section{Submit your manuscript to a SpringerOpen ${ }^{\circ}$ journal and benefit from:}

- Convenient online submission

- Rigorous peer review

- Open access: articles freely available online

- High visibility within the field

- Retaining the copyright to your article

Submit your next manuscript at $\boldsymbol{\nabla}$ springeropen.com 